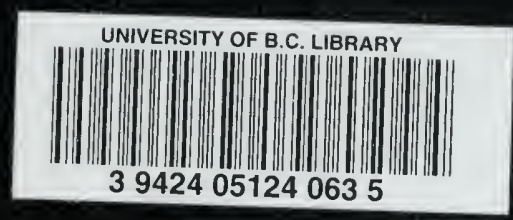

U. S. DEPARTMENT OF AGRICULTURE FOREST SERVICE GIFFORD FINCHOT, Forester

\title{
MANUAL OF PROCEDURE
}

\author{
FOR THE FOREST SERVICE \\ IN WASHINGTON AND IN \\ DISTRICT OFFICES
}

NOVEMBER, 1908 

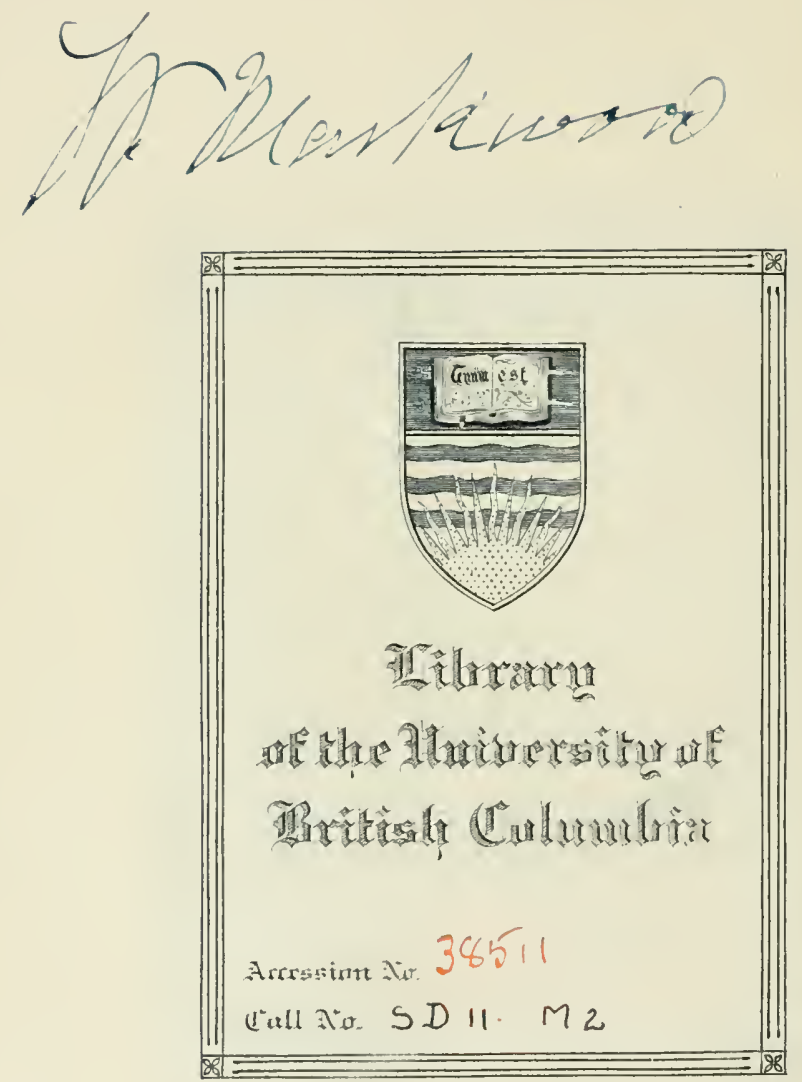


Digitized by the Internet Archive in 2010 with funding from University of British Columbia Library 

U. S. DEPARTMENT OF AGRICULTURE, FOREST SEIRTICE.

GIFFORD PINCHOT, Forester.

\section{MANUAL OF PROCEDURE}

FOR T'HE FOREST SERVICE

IN WASHINGTON AND IN

DISTRICT OFFICES.

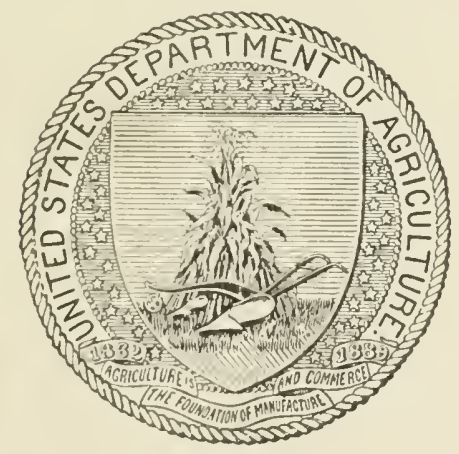

WASHIN(TOON:

GOVERNMENT IRINTIU OFFICE.

1908. 


\section{U. S. Department of Agriculture, Forest Service,}

Wastington, D. C., November 5, 1.908.

The procedure described in this Manual will be followed strictly by all members of the Service in Washington and in District Offices. Where knowledge of this procedure is essential to officers on National Forests, because of changes made in the procedure described in the Use Book, or for other reasons, this type is used.

Giffond Pinchot, Forester.

Approved:

James Wilson, Secretary. 


\section{(1) NTENTS}

Organization ....

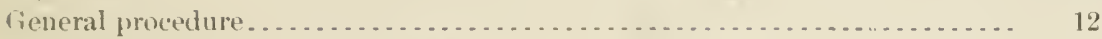

Regulations and official orlers................................ 12

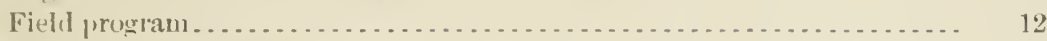

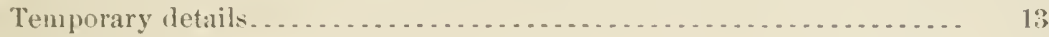

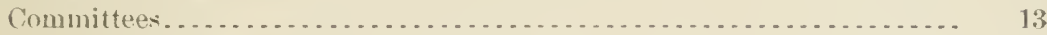

District offices.............................................. 13

District rommittee. . . . . . . . . . . . . . . . . . . . . . . . . 13

Washington ............................................ 1:3

Service committee.................................. 13

Committee on business methods......................... 14

Library committer ................................... 14

Photograph committee ............................. 14

Instrument committee................................ 14

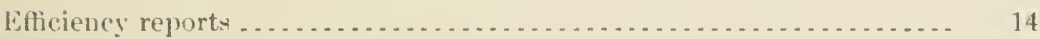

Material for publication .......................................... 14

Comlemnation or loss of property . . . . . . . . . . .

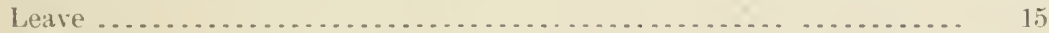

Classification of correspondence . . . . . . . . . . . . . . . . . . .

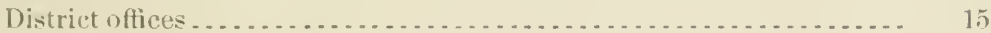

Service correspondence .............................. 15

District correspondence .............................. 16

Othice correspondence.............................. 16

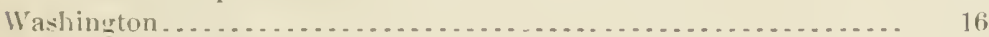

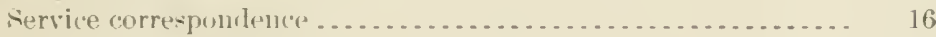

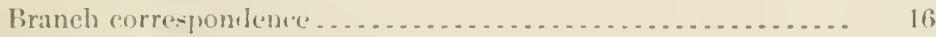

Oftice correspontence................................ 17

signing of torrespondence...................................... 17

Distribntion of mail receiverl ................................... 17

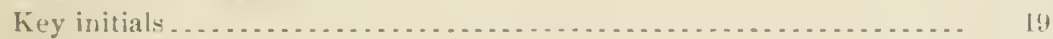

Form of correpondence . . . . . . . . . . . . . . . . . . . . . . . . . . . . $\quad 19$

[rate....

Aildris. . . . . . . .

Superscription ......................................... 20

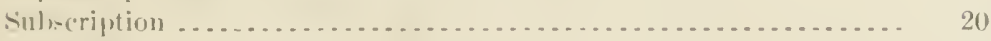

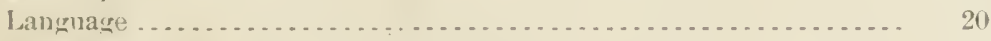

Pronines................................................ 21

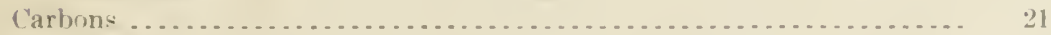

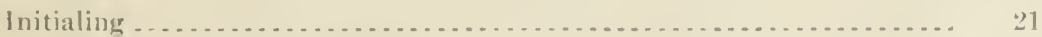

Arrangement of letter for signature ........................

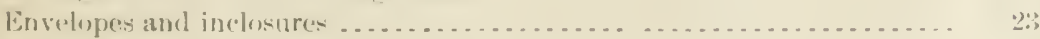

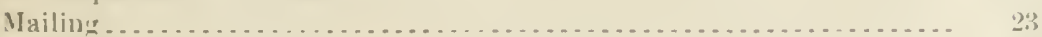

Registerml mail .................................... 24 
General procedure-Continued.

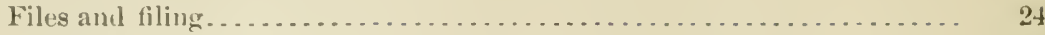

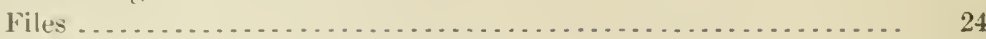

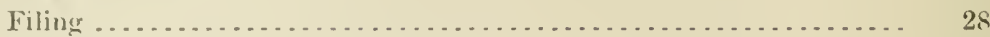

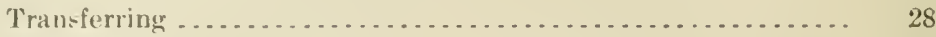

Withdrawals ..................................... 29

Examination of records by the public........................ 29

Procedure by units in organization . . . . . . . . . . . . . . . . . . . . . . . 30

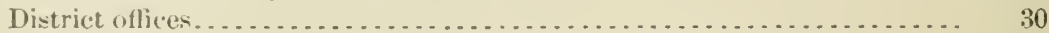

Uttic of the District Forester........................... 30

Duties ......................................... 30

Annual estimates.................................. 30

Allotment estimates .......................... 30

Appropriation estimates ......................... 31

Promotions ..................................... 31

Law .................................................... 31

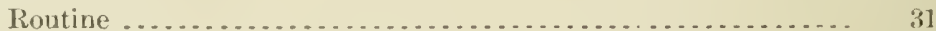

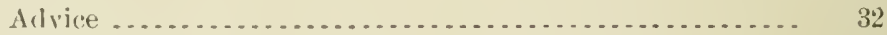

Approval of legal documents and correspondence......... 32

Claim contests .................................. 33

Court cases ........................................... 33

Briefs and arguments......................... 33

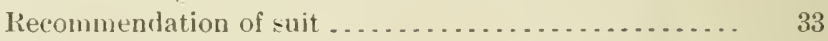

Index (ards.................................. 33

Collection of state forest laws ................... 33

Miscellaneous projects........................ 33

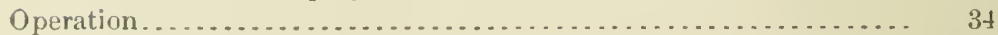

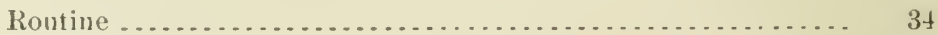

Organization .................................... 34

Allotments to Forests........................ 34

Personnel..................................... 35

Eligil,le list ................................. 35

Supervisors' persomel reports.................. 35

Meetings of Forest officurs...................... 36

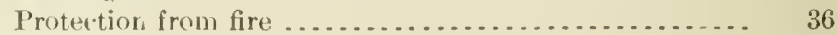

Fquipment and supplies for forests .............. 36

Rerommendations for advertiving................ 36

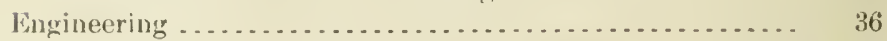

Complete plans for improvements . . . . . . . . . . . . . 36

listimates for improvements.................... 37

Allotments and authorizations for improvements ...... 37

Record of projects. . . . . . . . . . . ............ 37

Supervisors' reports........................... 37

Vouchers for improvement work ................. 38

Distriet atlas . . . . . . . . . . . . . . . . . . . . . . . . 38

Alienation . . . . . . . . . . . . . . . . . . . . . . . . . . 38

I) rafting and blueprinting.................... $\quad 39$

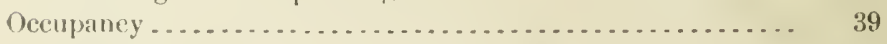

Boundaries ............................... 39

Ranger stations........................... 40

Claims................................. 41

Settlement.............................. $t 1$

Stecial uses ................................ 43 
Procedure by units of oryanization-Continned.

District offices-Continued.

Operation-Continued.

Routine-Continued.

Page.

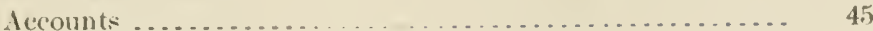

Allotment ledger ............................ 45

Dishurvement ledger.......................... 46

Cashhook................................ 47

1)uplicate chereks ............................ 47

Verification of depository halance .............. 47

Treasury zettlement of raims .................. 48

Daily dishursing balance....................... 48

Allotment and lislility recurd................... 48

Allotment cards f.r ofhers and sections ............ 48

salary allotment card...................... th

Individual salary (ard ..................... 49

Gerieral expense allotment card .............. 49

Individual expense carl ...................... 49

Cooperation allotment cards.................. 49

Allotment cards for Forests..................... $\quad 50$

Stlary allotment card...................... $\quad 50$

Jndlivilual salary (aril ....................... 50

Gieneral expense allotment card ............... 50

Improvement allotment card.................. 50

Fire allotment card........................ $\quad 50$

Conperation allotment card .................. 51

Transfer of salary card ........................ 51

Voncher and certification numbers ............... 51

Pront of entries ............................. 51

Monthly liability and financial statements .......... 52

Apointment record........................... 53

Persomel index............................... 53

Record of abseners ........................... 53

Requisitions for funds ........................ 53

Treaury notification of warrants issued............ 54

Certificates of deposit ......................... 54

Han lling of volhers for disbursement ............ 54

Audit ..................................... 54

Review ............................... 55

Payment .................................. 55

Analysis of forest disbursements................. 55

V'oncher register ..... ........................ 55

Littlefielit report ............................ $\quad 56$

Special disburcing agent's vonchers and abstracts ...... 57

Receipts and refunds ...................... 57

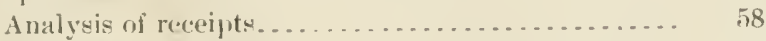

Analysis of refunds........................ 58

Compariom of receipts...................... 58

Report of receipts and refunds . . . . . . . . . . . . .

Abstract of disbursement . . . . . . . . . . . . . . . . $5 !$

Accounts current. . . . . . . . . . . . . . . . . . . . . . . 59

Traniportation reyuests and mileage books.......... 59

Ilentification ('ards........................ (i)

Autlurizations for advertising. . . . . . . . . . . . 60 
Procedure by units of oryanization-Continued.

District oflices-Continued.

Uperation-Continued.

Routine-Continued.

Page.

Maintenance.................................. 60

Quarter................................. 60

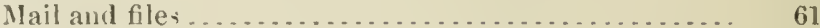

Equipment ................................. 61

Stenography and typewriting. . . . . . . . . . . . . . . . 61

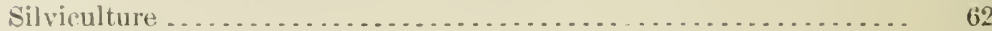

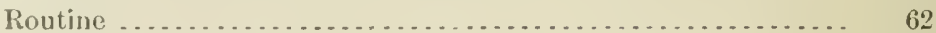

Timber sales ......................................... 62

Class $\mathrm{A}$ and unadvertised Class B sales............. 62

Advertised Class B sales ...................... 63

Class C sales ............................... 63

Timber settlement.............................. 64

Supervisor's permits....................... 64

District Forester's and Forester's permits........ 65

Administrative use ......................... 65

Free use ...................................... 65

Supervisor's permits . ....................... 65

Di-trict Forester's permit, ................. 65

Modifitation of contracts...................... 65

Cancellation of contracts . . . . . . . . . . . . . . . . . 66

Timber tres]ass ............................ $\quad 66$

Sawmill permits.......................... $\quad 66$

Supervisor's permits.................... 66

District Forester' $\mathrm{A}$ permits . . . . . . . . . . . . . . . 66

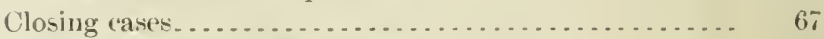

Summary of timber sale records. . . . . . . . . . . . . . 67

Estimates................................ 67

Stumpage rates............................ 67

Marking rules............................... 67

Reconnoissance studies ..................... 68

Field cost of timber sales. . . . . . . . . . . . . . . . . . 68

Federal cooperation ........................... 68

Indian Office................................. 68

Other cooperation ............................ 68

State and private cooperation .................... 68

State cooperation. . . . . . . . . . . . . . . . . . . 68

Private cooperation ......................... 69

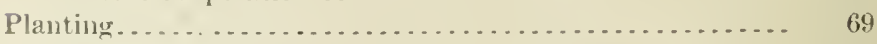

National forest planting . . . . . . . . . . . . . . . . . 69

Cooperative planting. . . . . . . . . . . . . . . . . . 70

Silvi(s...................................... 70

Lihrary . . . . . . . . . . . . . . . . . . . . . . . 71

Grazing ............................................. 71

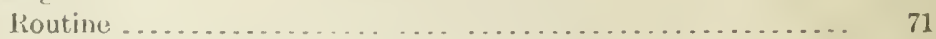

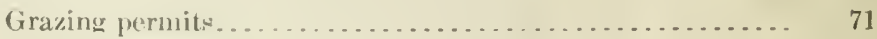

Authoriøation........................... 71

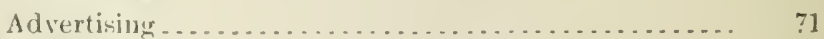

Notices of approval........................ 72

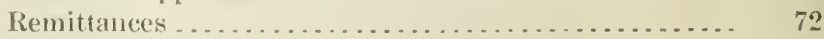

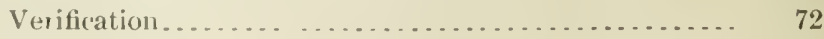

Private lands............................. 73 
Procedure by units of ormanization-Continued.

District ollices-Continued.

Grazing-Continued.

Routine-Continued.

Page.

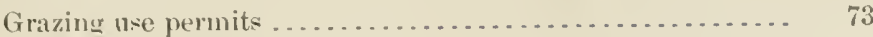

Payments..................................... 74

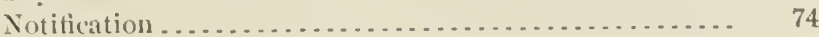

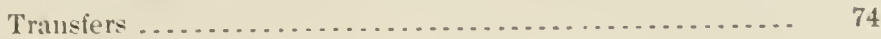

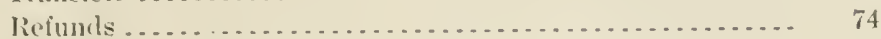

Trespass ............................................ 75

Recognition of advisory boards.................... 75

linforcenent of lederal and state quarantine regulations... $\quad 76$

Construction range improvements.................. 77

Killing of predatory animals ........................ 77

National game preserves ......................... 77

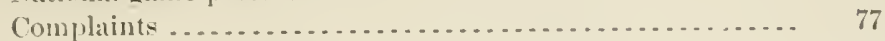

Appeals from supervisor's grazing decisions ............ 78

Cooperative agreements........................ 78

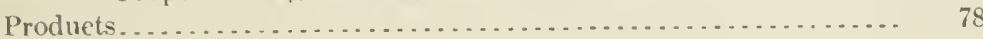

Routine .............................................. 78

Wood ntilization .................................... 78

Wood preservation ........................................ 79

Forest Service treating plants.................... 79

Cooperative treating plants.................... 80

Periodic reports to the Forester........................ 80

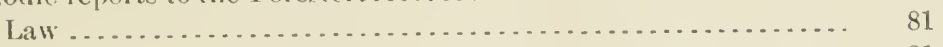

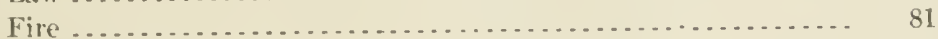

Distribution of service ............................ 81

Meetings........................................... 81

Permanent improvements ............................ 81

Bound, ris.......................................... 81

Ranger stations. . . . . . . . . . . . . . . . . . . . . . . . . . 81

Clims........................................... 82

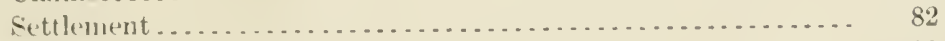

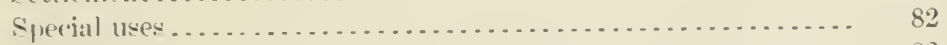

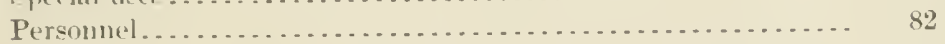

Littlefield.

Recripts and refunds ................................. 82

Liability statement ................................. 84

Financial statement ................................ 82

Temporary labor . . . . . . . . . . . . . . . . . . . . . . . . . . . 82

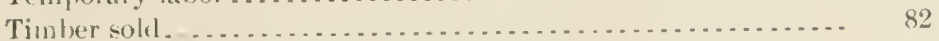

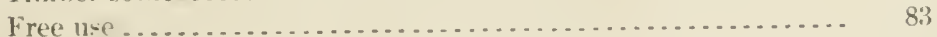

Maximun cut .................................... 83

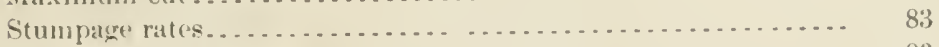

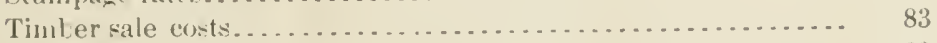

Croperation.......................................... 83

National forest planting... . . . . . . . . . . . . . . . . . . . . 83

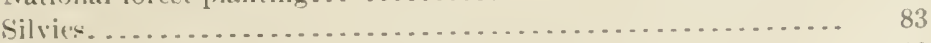

(irazing permits.......................................... 83

Grazing trespass........................................ 83

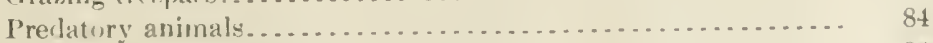

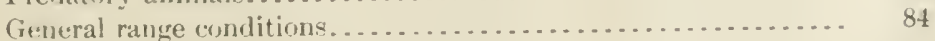

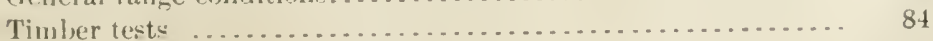


Procedure by units of organization-Continued.

District offices-Continned.

Periodic reports to the Forester-Continued.

Page.

Timber treatment .................................. 84

Market studies . . . . . . . . . . . . . . . . . . . . . . . . . . . . . 84

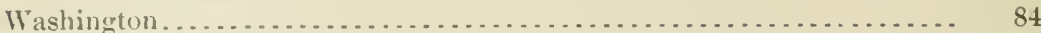

(office of the Forester ..................................... 84

law.................................................... 84

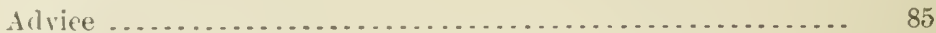

Approvil of legal forms, etc......................... 85

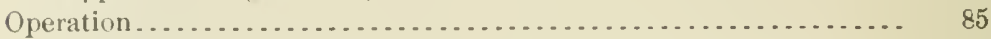

Occupancy........................................ 85

Rontine...................................... 85

Boundaries ................................ 85

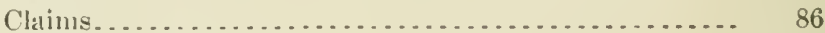

Special uses ................................. 86

Aecomnts ............................................ 86

Rontine.................................... 86

Appropriation lerlger ......................... 86

General allotment lerlger..................... 86

Treasury settlement of claims ................ 86

Requisitions for funds ........................ 86

Nolice of warrants issued $\ldots \ldots \ldots \ldots \ldots \ldots \ldots . . .68$

A ecounts eurrent............................. 88

Monthly financial statements.................... 88

A ppointments............................... 88

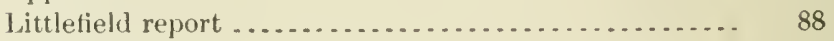

R ceipts ................................... 89

Authorizations for advertising.................. 89

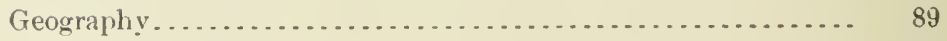

Rontine....................................... 89

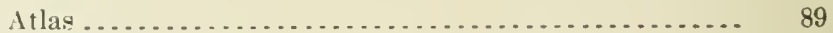

Alienation ................................... 89

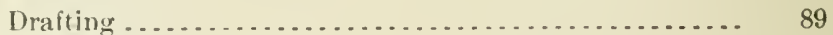

Photography............................... 90

Maintenance ....................................... 90

Silvieulture ..................................... 90

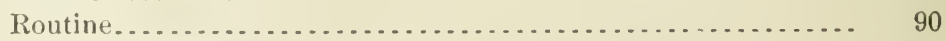

Cooperation.................................. 90

Silvics ..................................... 90

library ................................... 91

Books for nse in Washington................ 91

Books for District and supervisors' offices........ 91

Periodicals ............................... 91

Photouraphs .............................. 91

Lantern slides........................... 92

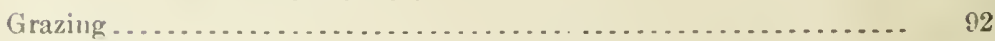

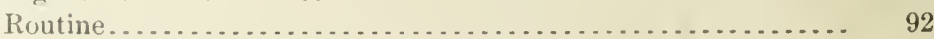

Grazing authorizations . ........................ 92

Federal and State quarantine regulations.............. 92

National game preserves ........................... 92

Appeal from 1)istrict Forester's grazing derisions........... 93

Products ........................................... 93 
MANUAL OF PROCEDURE FOR THE FOREST SERVICE. 


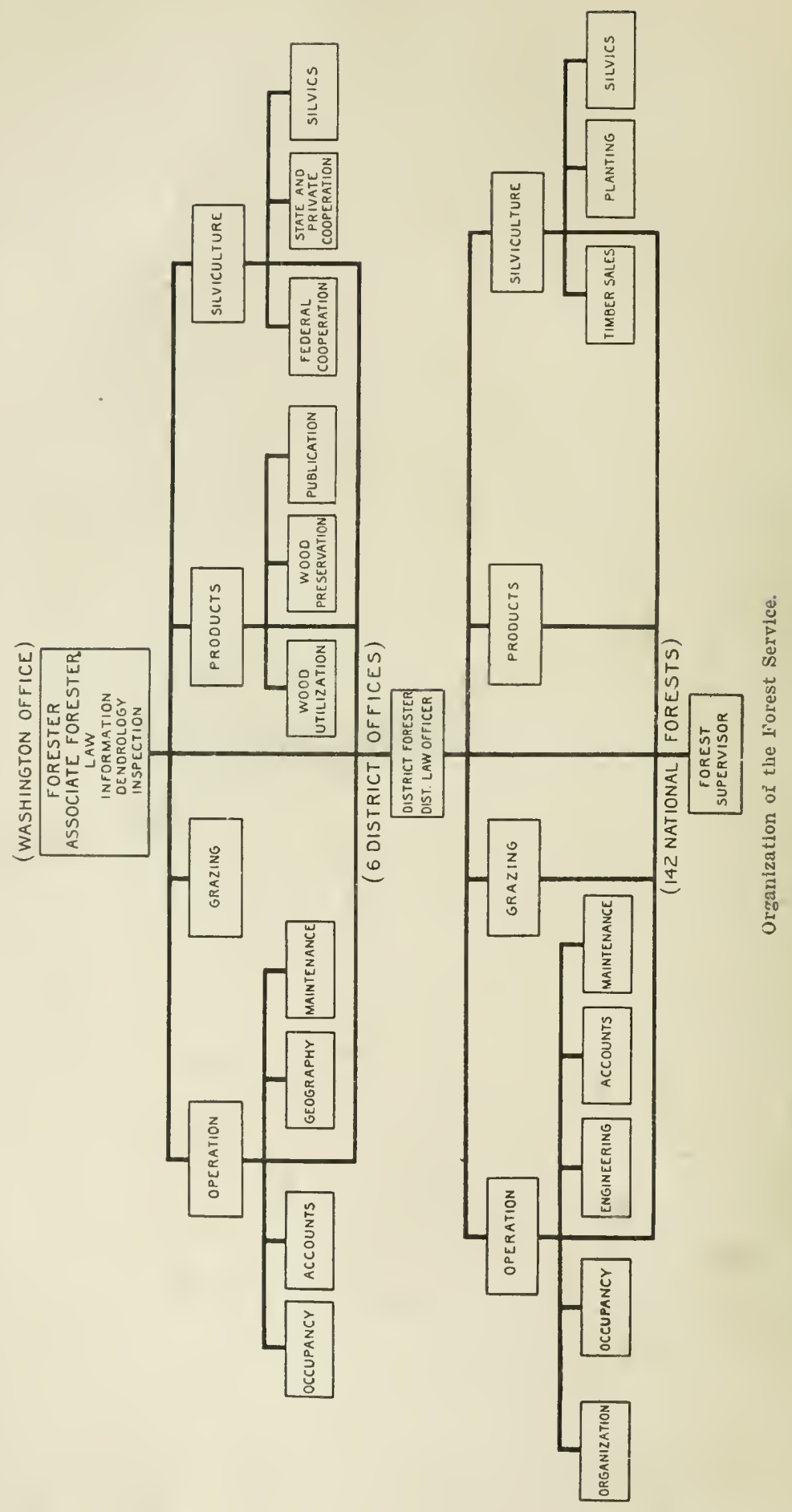




\section{MANUAL OF PROCEDURE IN WASHINGTON AND IN DISTRICT OFFICES.}

\section{ORGANIZATION.}

The chart, page 10, shows the organization of the Forest Service.

The administrative officer's of the Forest Service are the Forester, the Associate Forester, the Law Officer, and the Chiefs and Assistant Chiefs of Branch. The executive oflicers are the District Foresters, the Assistant District Foresters. Chiefs of Office and Section both in Mashington and district offices. and Forest oflicers in charge of National Forests.

Idministrative oflicers only are atuthorized within their respective fields to issue instructions to District Foresters. But only under grave emergency will administrative officers issue instructions, either in the field or from Washington. to any officer subordinate to the District Forester. In such cases the District Forestel concerned will immediately be informed in writing of the character of the instructions, and to whom they were given.

When on duty in a District, Chiefs of Office from $\mathrm{W}^{\text {rashington will. }}$ by assignment from the Chief of Branch, act either as Inspectors within their respective fields, reporting direct to the Chief of Branch, or as executive officers under the direction of the District Forester, with the status of District Chiefs of Office as hereafter defined. Members with headquarters at Washington below the rank of Chief of Office, while on cluty in any District, will always act under the instructions of the District Forester with the status of members of the District oflice below the rank of Chicfs of Oflice, as hereafter defined.

The District Forester, Assistant District Forester, and Chiefs and Assistant Chiefs of Office in the District organization are authorized, within their respective fields, to give instructions to oflicers on $\mathrm{Na}$ tional Forests within their Districts. Members of the District organization below the rank of Chief of Ollice. when on National Forests, will, by assignment from their Chief of Office, act as Inspectors within their respective fields, reporting direct to their Chief of Office. or', as executive officers, reporting direct to the Snpervisor.

Chiofs of Office from Washington and members of the District organization below the rank of Chief of Ollice, when on National Forests as Insperctore, will give mo orelors. 


\section{GENERAL PROCEDURE.}

\section{REGULATIONS AND OFFICIAL ORDERS.}

\section{DISTRICT OFFICES.}

When a District Forester finds it necessary to issue instructions under existing regulations to all officers on National Forests in his District. he will submit them to the Forester for publication as a note in the Field Program. Only when to await the next issue of the Field Program would involve serious delay will the District Forester issue such instructions in a circular letter to all officers on National Forests in his District, sending a copy to the Forester.

When written instructions to the District Office are necessary, the District Forester will issne them as a memorandum, and the file copy will be initialed to show receipt. In every case a copy of the memorandum will be furnished to the person who initials.

\section{WASIIINGTON.}

Notice of important changes in organization, new regulations, and modifications of existing regulations will be signed by the Forester and published in the Field Program as Service Orders in a numbered series. They will be mimeographed for distribution only in particularly urgent cases.

Regulations dealing wholly with the administration of the Service in Washington will be issued as Office Orders, in a numbered serics, and furnished to all Branches and Offices of the Service in Washington.

Transient instructions will be issued as memoranda.

\section{FIELD PROGRAM.}

The Field Program will be issued from Washington on the first day of each month. It will contain a directory of the Forest Service in Washington and by Districts, and, as hitherto, changes in personnel during the month, Service Orders, and instructions to officers on National fiorests in the form of notes originating in Washington or through the suggestion of a District-Forester. All orders and other instructions printed in the Ficld Program will apply to all Districts. Material intended for the Field. Program will be forwarded from District offices in time to reach Washington not later than the 24 th of the month.

A sufficient number of Field Programs will be sent, in envelopes, to each Supervisor to supply all officers on his Forest. Immediately upon their receipt the Supervisor will have the envelopes addressed and the Programs mailed. Sufficient Field Programs, not in envelopes, will be sent to District Foresters for immediate distribntion in District 
Offices. Necessary changes in the number sent any Supervisor will be indicated by him to the District Forester, who will so inform the Forester when he forwards material for the next issue.

\section{TEMPORARY DETAILS.}

\section{DISTRICT OFFICES.}

The District Forester will detail Supervisors, Deputy Supervisors, Forest Assistants, and in cases of special efficiency, Forest Rangers, to assist as needed in the District Offices of Operation, Silviculture, Grazing, and Products. The total number of such details to any District 0 ffice for any one year should not fall below 20 men, and may exceed it when necessary. Only in cases of emergency will the period for which any one man is detailed to a District Office exceed six weeks in any one year.

\section{WASIIINGTON.}

'To keep close touch between officers in Washington and in District Offices, and to aid in the administration of the Forest Service, the Forester will call the following District officers to Washington anmually for a detail of approximately one month each: District Foresters, Assistant District Forester's, District Law Officers, and the Chiefs and Assistant Chiefs of Operation, Silviculture, Grazing, and Products.

\section{COMMITTEES.}

\section{DISTRICT OFFICES.}

The District Committee will comprise the District Forester, who will be chairman, the Assistant District Forester, the District Latw Officer, and the Chiefs of Operation, Silviculture, Grazing, and Products. The Committee will meet every Tuesday without fail.

The following order of business will be observed:

Reading of the minutes.

Discussion of efficiency reports.

Reports of subcoinnittees.

Discussion of reports of subcommittees and of District forest matters.

The District Committee will make definite recommendations, but decision will rest with the District Forester.

\section{WASHINGTON.}

The Service Committee will comprise the Forester, the Associate Forester, the Law Officer, and the Chiefs of Branch. The order of business will be as outlined above. 
The Committee on Business Methods will report to the Forester plans for new methods of routine business and changes in the system of correspondence, filing, bookkeeping, and office procedure generally. New forms and changes in existing forms will be submitted to this Committee for approval, which, on its own initiative, will recommend to the Forester advisable changes in business methods.

The Library Committec will make and pass upon recommendations for the purchase of books for use in Washington and in District and Supervisors' offices.

The Photograph Committee will examine prints of all photographs taken by members of the Service, and will make recommendations for additions to the collection, and for the gift, loan, or sale of photographic material.

The Instrument Committee will recommend the kinds and type of instruments and field equipment for use by the Service.

\section{EFFICIENCY REPORTS.}

\section{DISTRICT OFFICES.}

Each Chief of Office will submit, in duplicate, the day before each meeting of the District Committee, an Efliciency Report on Forms 52 and 53, covering the business of his Office for the past calendar week.

The Efficiency Report will be accompanied by a concise memorandum, which should include:

A brief statement of progress made upon projects or investigations under way whenever there has been progress worthy of mention.

A statement of important projects undertaken or business begun.

A statement of any occurrences or developments that have arisen in the course of the business of the week.

As a basis for this memorandum each Office and Section will keep a daily note of business to be reported.

One copy of the Efficiency Report (Forms 52 and 53) and of the accompanying memorandum will be sent to the Forester.

\section{WASHINGTON.}

The above procedure will be followed to cover the work of each Branch, except that Forms 50 and .51 will be used.

\section{MATERIAL FOR PUBLICATION.}

\section{DISTRICT ONEICES.}

Before material is prepared for publication a synopsis of the proposed publication will be submitted to the District Forester, who will 
submit it to the Forester for approval. Manuscripts for publication should bear the initials of the author, the Chief of Office concerned, and the District Forester.

\section{WASHINGTON.}

The same procedure will be followed in Washington, except that synopses and manuscripts will be approved by the Chief of Branch.

\section{CONDEMNATION OR LOSS OF PROPERTY.}

\section{DISTRICT OFFICES.}

Certificates to the condemnation or loss of property (Forms 858 and 217) charged to members of the District Office or to officers on National Forests will be initialed by the Chief of Office concerned, signed by the District Forester, and sent to the Property Auditor at Ogden.

\section{WASHINGTON.}

The above certificates covering property charged to members with headquarters at Washington will be initialed by the Chief of Branch or Office concerned and signed by the Forester.

LEAVE.

\section{DISTRICT OFFICES.}

Chiefs of Office will approve applications from members of their Offices. Applications from Supervisors will be approved by the Chief of Operation. Applications from Chiefs of Office will be approved by the District Forester.

\section{WASHINGTON.}

Applications for leave from members with headquarters at Washington will be made upon the forms and under the procedure prescribed by the Department of Agriculture.

\section{CLASSIFICATION OF CORRESPONDENCE.}

DISTRICT OFFICES.

The correspondence of District officers will comprise Service, District, and Office correspondence.

Service correspondence will be submitted for the signature of the Forester, and, in addition to the classes later defined, will comprise:

Letters involving new questions of general policy.

Other letters which in the judgment of the District Forester are of sufficient importance to require the signature of the fiorester.

The District Forester will, whenever practicable, submit letters for the signature of the Forester, replying to correspondence of these two 
classes, and not merely statements suggested as the basis for the preparation of replies in Washington.

District. Foresters will correspond dircetly with officers not in Washington of other Bureaus in the Department of Agriculture and in other Departments, when to correspond through Washington would seriously hamper work, provided such correspondence does not deal with matters of general policy which fall properly to the Forester. Except as specifically provided herein, District Foresters will not correspond directly with officers in Wrashington of other Bureaus or Departments.

District correspondence will be signed by the District Forester, and will comprise-

Letters to the Forester written in the District Office.

Letters dealing with matters affecting the District as a whole.

Letters materially affecting the standing of any Forest officer.

Letters of allotment and of authorization.

Contracts and permits approved in the District Office.

Office correspondence will be signed by Chiefs of Office, and will comprise correspondence not included under Service or District correspondence.

\section{WASIIINGTON.}

Service correspondence will be signed by the Forester, and will comprise-

Letters involving matters of policy affecting the Service as a whole.

Letters which in the jurlgment of the Assistant Foresters are of sufficient importance to reçuire the signature of the Forester.

Letters maling allotments to Branches and Districts.

Very important contracts.

Branch correspondence will be signed by the Assistant Foresters, and will comprise-

Letters dealing with matters of policy affecting the Branches but not the Service as a whole.

Letters involving more than one Office of any Branch.

The following classes of correspondence will be signed as Acting Forester by the Assistant Forester in charge of the Branch concerned:

Letters relating directly to the business of the Branch but which must. in accordance with law or regulation, be signed by the Forester or Acting Forester;

Letters making allotments to offices and letters of authorization under them;

Contracts binding the Service but not of sufficient importance to require the personal attention of the Forester or the Associate Forester, and which follow established policies. 


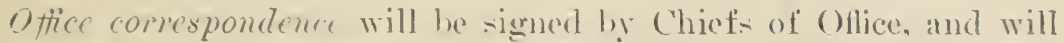
comprise correspondence not inchided under service or Branch correspondence.

\section{SIGNING OF CORRESPONDENCE.}

Neither in Washington nor in District or Supervisor's' Offices must the absence of any officer interfere with prompt action upon correspondence. When final action can not be taken at once. the letter should be acknowledged immediately and the correspondent informed of the date upon which action will be taken.

\section{DISTIRT OFFICES.}

In the absence of the District Forester. District correspondence will be signed as Icting District Forester by the Assistant District Forester. vimilarly, in the absence of a Chief of Office, correspondence will be signed as Icting Chief by the Assistant Chief.

Except in energency and under the written authority of the District Forester, no nember of the Disurict Oflice below the rank of Chief or Assistant Chief of Office will sign mail to Forest officers or to the public, and then only as Acting Chief of the Office concerned. But mail relating to the actual settlement of accounts will bo signed by the District Fiscal Agent.

\section{W.ANINGTON.}

Letter: to I)istrict Foresters will be signed only by the administrative oflicers of the Forest Serrice. Ietters to the public will be signed by members in Washington below the rank of Chief or Assistant Chief of Oflice only when authorized hy the Chief of Branch (oncermerl, and then only as Icting (hief of Office.

\section{DISTRIBUTION OF MAIL RECEIVED.}

\section{IDISTRIT'T OFFICES.}

The mail clerk will open and refer to oflices by rubber dating stampe all letters and telegrams except letters obviously personal, which will be delivered unopened. 'Telegrams will always be referred by nessonger immediately upon rereipt.

Upon request of any (ofliwe the mail clerk will refer specifier classes of ineoming mail to the file clerk, who will attach previoucorre-pondence (in designated transartions, the folder). to letters referred.

The Chief of each (oflice will decignate a member of hic () flice to

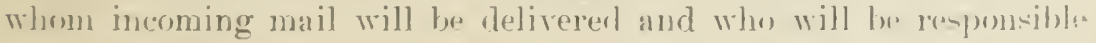


for its prompt distribution. Is receired from the mail clerk each letter will be stamped with the "Received" stamp of the Office, and numbered in the upper right-hand corner. At the same time a pink slip. 3 by 5 inches, will be attached. bearing the letter number, the "Received" stamp, the liey initials of the Office or Section in which the letter is to be answered, and the time limit for action. I duplicate of this record will be kept by the clerk who distributes the Office mail. The date of reply, or the fact that no reply is necessary, will be noted upon the pink slip, which will then be returned and filed for use in compiling the weekly Efficiency Report. Ifter this report is made the slip will be destroyed.

Throughout the course of the letter the pink slip will always be attached on top of all papers as a constant call to prompt action.

When a letter does not pertain wholly or mainly to the work of the Office to which it has been referred, the clerk charged with the distribution of mail in that Office will refer it by rubber stamp to the appropriate Office, where it will be handled in accordance with the above instructions.

T'hen a letter is answered or acknowledged the date will be entered upon it by the stenographer in the space provided in the "Received" stamp.

The District Forester will acknowledge letters requiring action by the Forester or by another District Forester on a postal card (Form 41) and refer them by rubber stamp. Only in those rare cases in which the form postal card is not sufficient will the acknowledgment be made by letter.

Each member who prepares letters will keep a basket on top of his desk, in which only unanswered letters or other matter for action will be placed. Unanswered letters or other papers dealing with unfinished current business must not be kept in drawers or pigeonholes. Important papers will be safely put away at the close of the day.

\section{WASHINGTON.}

The procedure will be as prescribed for District Offices.

Letters requiring action by a District Forester will be acknowledged on a postal card (Form 42), and referred by rubber stamp. Only in rare cases where the form postal card is not sufficient will the acknowledgment be by letter.

Tetters referred from the office of the Chief Clerk of the Department of Agriculture will be distributed in the same manner as other letters. The mail clerk will keep a record of the receipt and reference of such letters to insure the prompt return of the jackets. on which the zetion taken will be noted. 


\section{KEY INITIALS.}

DISTRICT OFFICES ANT WASHINGTU.

Every letter dealing with a desimnated transaction or subject will bear its designation directly abore the first line of the address. Members signing mail will see that this rule is observed, since correct filing depends upon its observance.

Key initials (See Forms ts and 49) will be used for referring memoranda and other papers in Washington and in District Offices. When a document is sent to several Offices or Sections a slip upon which their key initials are entered will be attached, and the key initials crosed ofl as action is taken by each Office or Section.

Each letter written in Trashington or in a District Office will bear in the upper left-hand corner the key initials of the Branch, Office, or Section charged with the class of business dealt with in the letter.

\section{FORM OF CORRESPONDENCE.}

\section{DISTRICT OFFICES AND WASHINGTON.}

All letters will be double spaced, except for quotations, which will be single spaced.

No soiled or rubbed letter will be signed, nor any letter in which corrections are carelessly made.

Copying ribbon will be used for letter's prepared for the signature of the Secretary of A grieulture, and for letters of special importance signed by the District Forester; as, for example, those of which copies might be needed as evidence in legal action. Care will be taken that the ribbon is changed often enongh to insure good press copies. All other letters will be written with black record ribbon.

Letters should have a margin of approximately 1 inch on both sides of the page.

All legal documents will be written on letter-size paper.

The pages of all documents and letters except those of only one page will be numbered at the bottom of the page, in the middle. To give space for the number, the last line, should be at least three-quarters of an inch from the bottom. When a letter is of more than one page, all pages except the first will bear the initials of the person addressed, on the left side in a separate line at the top.

All memoranda and typewritten scratch copies will be on yellow paper. Correspondence and final reports for use outside the Service will be on white paper.

(1). ITF.

The date should be about half an inch below the lowest printed line on the letter head. The month should not be abbreviated. Figures only should be user for the day, as " March 30.' 
The date will be onitted in letters prepared for the signature of the Secretary of Ierienlture until they have been initinled by the Forester. and in letters prepared in District Oflices for the signature of the forester.

AHDRESS.

The name and address should be double spacea when they take but two lines, and single spaced if more than two.

Special care will be taken to prefix the correct title, either official or honorary.

The official title will be omitted from letters written to nembers of the Service by name.

\section{STPERACLIPTIOX.}

"Dear Sir" should ordinarily be used. Only in very formal letters should "Sir" be used. Titles should be written out.

\section{SCBSCRIPTION.}

With "Sir: " use "Very respectfully:" with "Dear Sir:" "Very truly yours:" with "Dear Mr. ——, " or " My dear Mr. —_," "Very sincerely yours."

\section{L.ANGUAGE.}

Use direct. clear-cut language. Avoid odd or unwieldy words when shorter, simpler ones will express the idea equally well. Be concise but courteous. Avoid laborious statements. the essence of which might well be expressed in half the space. Very few letters need be longer than one page.

Never use the substance of the letter received as a preamble to the reply. Unless the letter to be answered has already been acknowledged and further reference to it is necessary, its contents should not be indicated in the initial sentence. Reference must always be made, however, to file numbers or initials given for identification.

For acknowledgments or replies, the initial sentence should usually be in this form: "Your letter of Marcl 30 is received." In addressing the Forester, the I)istrict Foneter shomld refer" to the key initials on the letter answered, and its late: for example: " lom letter (on) of March 30 is received."

In referring to National Forests the words "Forest" and "Forests" will always be capitalized.

The previous or the following month should be named and not indicated by " ultimo" or "proximo."

The following words and phrases used in commercial correspondence should be avoided: "Aforesaid;" "Answering your letter;" "ere" instead of " before:" "extend courtesies," etc.; "I beg to say;" "I have 
to state: " I will say; " I would say; " in regard to the same;" "our Mr. _ : " " pleased " (as "I am pleased to learn ") ; "relative to:" "said report:" "your favor;" the present participle at the beginning of the last sentence of a letter, as "Thanking you for your kindness in this matter."

The phrase "you will " should not be used in giving orders or instructions. It is peremptory without adding force, and a friendlier tone is more courteous as well as more effective.

Severity of expression will be avoided in conveying reprimands in correspondence.

It should be borne in mind that the purpose of punctuation is a clear understanding of the text by the reader. Too little punctuation is almost as bad as too much.

\section{PROMISES.}

Wher a promise is made, do not use such indefinite phrases as "within a few days." "before long." Specify the date upon which action will be taken, or, in the rare cases when that is impossible, give the approximate date. The promise card system should be fully used for recording promises (U. B., p. 197).

\section{CARBONS.}

Each letter and telegram written in the Service will be prepared with one carbon copy, unless additional copies are needed for reference.

DISTIRT OFFICES.

Each letter witten in District Offices for the signature of the Secretary of Igriculture or of the Fore:ter will be prepared with three carbon copies. Two will be sent to Washington with the letter for ignature, and the third held in a waiting file by the file clerk. Upon the receipt from Washington of one cirbon stamped with the signature of the Forester. the carbon in the waiting file will be restroyed.

\section{W.ISHINGTON.}

All leter- prepared in Tashington will be written with one culbon copy. When a letter prepared in a IDistrict Oflice is signed by the Forester. one of the two carbons which accompanied it will be filed, and the other will be stamper with the signature of the Fore-ter and returned to the District (Jflice.

\section{INITIALING .}

\section{- IHSTLICL OHFICH.}

When a letter is of more than on patec all initialing will be on the first patge of patch carborl.

signature- will not be stamper on cartome until after loller-are signed. 
Letters written in a District Office will not be initialed on the nriginal. The carbon will bear in the lower left-hand corner the written initials of the author, of the Chief of the Office in which the letter was prepared. and, if the letter is to be signed in Washington. of the District Forester. The initialing for authorship will be omitted when the District Forester or the Chief of Office himself dictates and signs the letter.

When a letter or document prepared in one Office is of interest to another Office. it should be initialed by the Chief of the latter, to signify his concurrence or to fix his responsibility for carrying ont proposed work which falls to him.

The stenographer will stamp his initials in the lower right-hand "orner" of each carbon. If the letter" contains inclosures, or if future action is promised. the stenographer will stamp his initials twice. as a guaranty that the inclosures have been prepared, or that the action promised has been noted. When this action can not be taken immediately, a promise card will be prepared, retained by the stenographer, or given to any other person responsible for taking the action promised. When a letter entails typewriting by one stenographer and the preparation of inclosures or other action by another, the initials of both stenographer's will be stamped in the lower righthand corner of the carbon.

When the signer makes any changes with the pen, in a letter of which he is not the author, he will send it to the author in order that the changes may be noted and entered on the carbon, before the letter is sent to the mail clerk for mailing.

The above procedure applies equally to telegrams.

In signing or approving memoranda, requisitions, and other interior papers, only the initials will be affixed.

Absolutely without exception, every statement, memorandum, map, or document of any kind will be dated, and initialed for authorship.

\section{TASHINGTON.}

The above procedure will be followed, except that letters for the signature of the Forester will bear the initials of the Chief of Branch concerned, and that letters for the signature of the Sccretary will be initialed by the Forester in the upper left-hand corner.

\section{ARRANGEMENT OF LETTERS FOR SIGNATURE.}

\section{DISTIICT OFFICES AND WASHINGTON.}

In arranging letters for signature, the stenographer will place on top the letter to be signed, then the carbon copr. then the answered letter or other papers, and last the addressed envelope. When a letter is to the Forester, to a District Forester. or to a Forest Supervisor. the envelope will be nmitter (see Mailing). In arranging several 
related papers for signature. each place will be indicated by inserting a half sheet of yellow paper.

When a letter is of more than one page, the page for signature will be placed on top. 'This procedure does not apply to carbons.

In arranging letters witten with copying ribbon, the stenographer will fasten a sheet of yellow paper over the first page to lieep it from becoming blurred.

\section{ENVELOPES AND INCLOSURES.}

\section{IISTRIC'T OHFICES AND WASHINGTON.}

The stenugrapher will alduess envelopes for all letters except those to the Forester, to a District Forester. or to a Forest Supervisor (see Maling) before submitting the letters for initialing or signature.

'The stenographer will place in the envelope the inclosures to accompany letters, except those to the Forester, to a District Forester, or to Forest supervisors, when they will be securely clipped behind the letter for signature.

\section{MAILING.}

LISTRICI OFFICES AND WASHINATON.

The messengers will deliver signed letters, with accompanying papers. direct to the mail clerk, who will be responsible for all mailing.

The mail clerk will use envelopes bearing the printed address, $\therefore$ Forest Service, Mashington, D. C.," for all letters to the Forester. Letters to District Foresters will be mailed from Washington in envelopes printed "Forest Service," and the address of the District headquarters. Letters to Forest supervisors will be put in envelopes printed "Forest Supervisor:" and the post-office address. These envelopes will be kept open until the end of the official day, when they will be sealed and sent by messenger to the post-office. Other.letters will be put in the envelopes addressed in the Branches or Offices.

Is letters are placed in the envelopes by the mail clerk the answered letters, with the carbons attacher. will be delivered to the file clerk.

Mail clerks in District Offices and in $\mathrm{W}^{\top}$ ashington will keep an arenrate count of all oflicial letter's receiver and mailed by oflices, and will submit at the end of each month a statement embodying this information.

Lnsigned telegrams will under no circumstances he placed in the messenger $\$$ basket. but will be sent direct by messenger for initialing or signature. The messenger will in every case find the person or perons who-e initial or signature is leguired, if in the building. 
and if out of the building will at once report to the person by whom the telegram was prepared. When signed, the telegram will be delivered to the mail clerk for forwarding. When a telegram is written at or near the close of office hours the person by whom it is prepared will make sure that it is signed and sent before leaving for the day.

Registered Mail.-Letters of peculiar importanee or of whose receipt a record is essential, and valuable maps and documents, transportation requests, and instruments will be registered.

The mail clerk will list upon the post-office receipt blank, with one carbon copy, each piece of matter sent to the post-office for registration. The messenger to whom the matter for registration is intrusted will initial the post-office receipt and the carbon copy. The mail clerk will retain the carbon until the post-office receipt is returned by the messenger. The carbon will then be restroyed and the signed receipt filed by the mail clerk.

\section{FILES AND FILING.}

DISTRICT OFFICHS.

FILES.

Only those records which are specifically intended for use in an Dffice will be kept there. These inchude books or cards for daily or periodic entry, and abstracts of data used as a guide in the preparation of correspondence.

Correspondence and records filed in District offices will be assembled in a central file room, and will be in the custody of a file clerk and under the superrision of the Chief of Maintenance. Only vertical files will be used. Files will be of the following classes:

1 general correspondence file, in which will be filed alphabetically, withont reference to Forests or subjects, all correspondence which bears the letter $\%$ after the key initials, insteal of a subject designation (e. g.. $1 \%, 0 \%, 00 z)$.

Subject files. by Offices, in which will be filerl. under subjects, all correspondence which bears a subject designation.

The following designations will be entered (see examples) upon correspondence to be filed by subject, and will constitute a guide for filing:

1) Ihatrict linester. ('orrespontence originating with the llistrict Forester which deals with a sulject for which a lesignation is preseriber will bear that designation and the key intials of the dothe conerernet. 


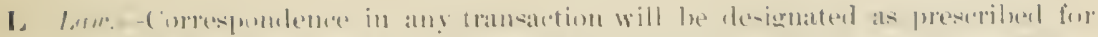

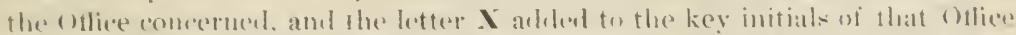

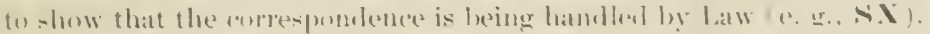

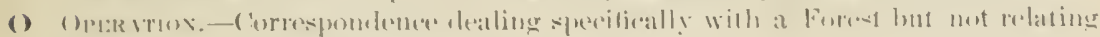

()

rike. to a lexignateel sirbjered.

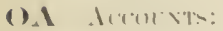

Forumigle:

O I

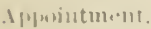
(1) 1

[ishura'tuent, ]'ike.

(inirles: forreste (mo Golders).

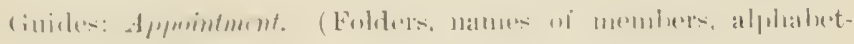
irally.)

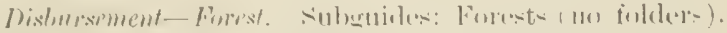

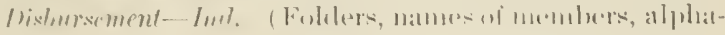
betically.)

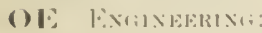

(1):

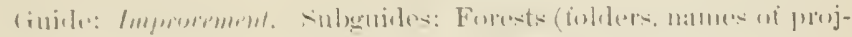
lmpirmem, Pike,

flull liuk - iatiul,

barn. 72004 .

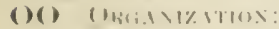

\section{() (1)}

l'ik. Illutment1.

\section{(1)}

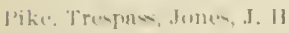

1 21$) 118$.

\section{(1)}

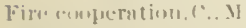

at: 1 . Ry.

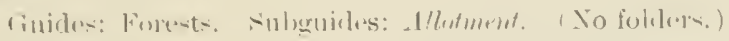

lires. (Xis fulders.)

fersonmel. 1 So finlelers.

siluerisimn. (Xil inleles.)

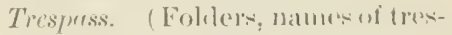
lasitro, aly)halx+tically.)

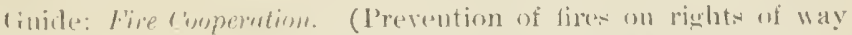
and private holrlings entigums ter Sational Foneste; foleless, names oi (ooperaters, alphalueticalls.)

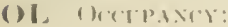

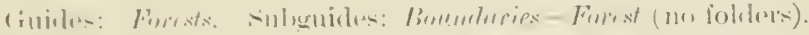

(1) I.

leike Bumblaties

Forum.

(1).

I'ikt, \& laims, Julles, I. II

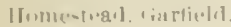

\section{(1)}

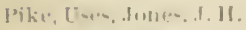
IIntor, I $201 \mid \mathrm{s}$.

\section{(I)}

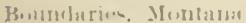

Trumball Y6motaim
Bomdurips- vitfiom (folderes, names of tatim, alphalutically).

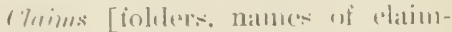
ants or mines (alphaluetically), datis of claim, amd lamm district]. settlemem (folders, nambe uf ilphli(ant-a alphalectieally).

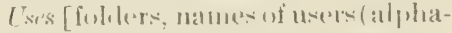
betically), alml (laks of His']

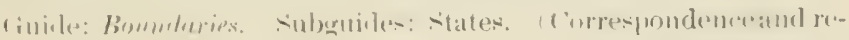
purtis regalims pros-

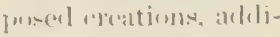
timns, ambl wimilıatimes; lulelurs, mannow oif projects, alpilialustit:ally.

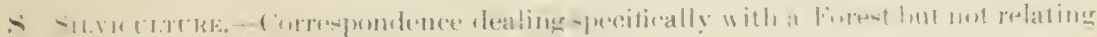
(1) al lievignated transiction. 
$\checkmark T$

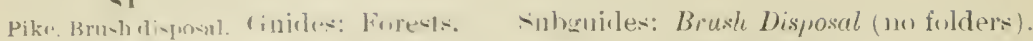

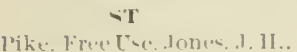
$\left.120^{\prime}\right)$;

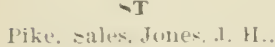
$120(1)$ listimates (no folders).

Free lise (folders, nanes of applicants, alphabetically).

Jurking liules (no folders).

sile Irolicy (no folders).

sales (indters, names of pur(hasers, alphabetically).

sammills (folders, names of ap)plicants, alphabetically).

vettlement (folders, names of applicants, alphabetically).

Trespass (folilers, names of trespassers, alphabetically).

\section{$-1$}

Cooperation, Fediral Indian Offiec. :

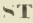

Cooperation. I'rivate. Junes. I. II.
Gnide: Conperution. Snbouirles: Federul (folders, names of rooyerating Departments and Bureaus, alphabetically).

Silnte (follers, names of States, alphabetically).?

I'ricate (folders, mames of cooperators, alphabetically).

SI Planteris:

Guides: Forests, Subguides: Vurseries (folders, names of nur-

\section{$\Delta \mathbf{r}^{\prime}$}

rike, Nurseries, Pikes leak.

\section{$\therefore 1^{\prime}$ \\ Pike, Serell. \\ ixi Silve:

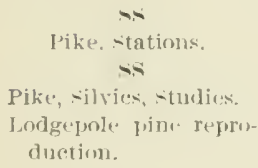

Pike, silvies, -tudies. lodgepole pine reproduction.

Tree stuclies, bonelas

Cinide: Tree Surlies (silvical studies of indivilnal species; foldurs, fir.

(i) Tikixit:
(:

I'ike, Allowances.

\section{G:}

I'ikt. rouperalion.

Yınเana.

(i:

pike fermils C. A H.

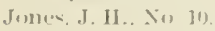

(iniles: Forests. Subquiles: statims (no folders).
Studies (silvical studies ly region
or Forests; folder, titles of
Studies (silvical studies ly reyions
or Forests; folders, titles of studies, alphaluetically).

Ilunting (planting of seedlings: or iseed outside of nurseries; no folders).

seed (collection and distribution of seed; no folders). names of species, alphabetically).

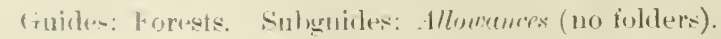

Cooperretion (folders, names of Bureaus, states, and private ("operators, alphahetioally).

L'ermits, Culle "rnil ILorsp's, Approved (folders, names of permittees, mumerieally).

J'ermits, sherp and Gouts, Aprocerl (iolders, names of permitters. ummerically). 
(i:

l'ike, l'crmits, - at ir.

Jomes, I. II. No. 310.

\section{(i}

liks, l'erutits, J'rivase.

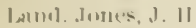

Pike. Truspus, June.s. .J.11

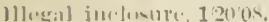

lermits, llistpprored applicalions (iolelers, mames of applicants. alpllabetically).

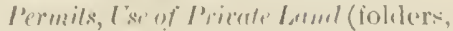
names of applinants, alphabeti('ally $r)$.

lirgulalions (explanation, or suggestions, for revicion: no follers). superrision (13) dulilers).

Trespess (folleles, names of trespassers, alphabetrally).

Fess (pastures, shift femers, stuck tamks. etr.; folelers, manes of applicants, ahphalodically).

finde: Sindies (range improvement and clevelopment; folders, names of projects, alphabetically).

I" J'เก็น'าพ:

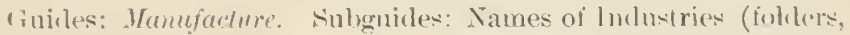
names of articles alphabetically).

Manufaciure, cimplerage, Staves

\section{1}

Markils. Montana Butte.

\section{I}

Mensuratinn. Volım, [nouglas lir, Orogon.

I'

Mencuraliul (irading rules. \&umler. YelJow leine Ylors. A $\cdots n$.

1'

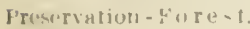
Jike.

I"

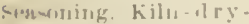
ius Vineer.

I"

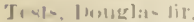

1"

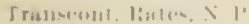
$\mathrm{ky}$.
Markets. Subguides: State (folders, name- of forests am towns, alphabetically).

Assuciation (folders, names of dstis)ciations, alphalsetioally).

Vensuration. Subguirles: Tolume, Ileight, Age, Groulh, Form, and sland.

Sulernicles: Names of sureries (folders, names of states, alpibabetically).

subguides: liedering forfficints (no bolders).

Sulguile: Gimling linles.

Subguides: Vames of materials (folders, mamess of alsociations, alphatretically).

Preservalion-Forest (folders, nanes of Forests, alphabeti('ally).

Presemation-forpmoralie (folders, namses of (") alpluabretically).

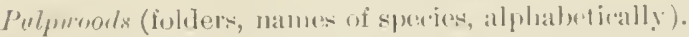

Seasoming. Sulnguides: Names of mothods (folders, names of mallorials, alphibeti(ally).

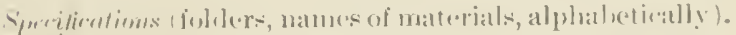

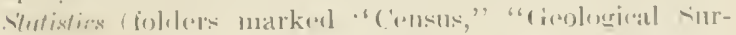

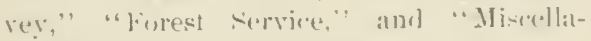
mentise").

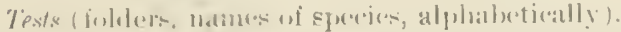

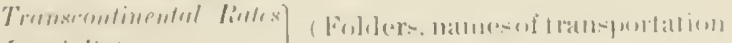

Lomerl lirrles

rarelle lictes

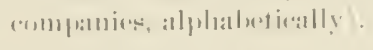

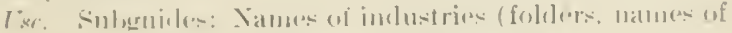
articles. alphaluetionlly!

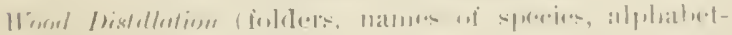
i.ally. 
Fill $\ \mathrm{G}$.

Is correspondence is received for filing. the file clerk will staple the earbon to the answered letter. When the carbon is not accompanied by an answered lotter, its pages will be stapled together as at unit for filing.

All correspondenre which beals the letter z after the key initials will be filerl. with accompanying papers, alphabetically by correspondent, in the General File.

Correspondence which bears a subject designation will, with accompanying papers, be filed under it, in the subject files.

correspondence which bears neither the letier z nor a subject designation will be returned. with accompanying papers, to the Office in which it originated, for the proper file designation.

When names of correspondents begin with the sane letter, filing. will be alphabetical by the spelling of the surnames: Is Jenkins, Johnson. Jones. Then the correspondence from two or more persons of the ame surname is filed together, it will be filed alphabetically by initials-as 1 . Jones. H. Jones. IV. Jones. If the initials are also the same, the spelling of the first name will be the guide to the filing-as Albert.Jones. Ilfred Jones, Arthur Jones. Correspondence filed under the same name will be filed chronologically, with the most recent letters on top.

Correspondence with members of the Forest Service and of other Bureaus and with State officials will be filed under the Office of the correspondent. and not under his name or title. Correspondence with officials of firms, assoriations, and other private organizations will be filed by the name of the writer when the letter does not relate to the business of the organization.

Circular letters will be filed as other correspondence.

Cross references will be made only when the name of a correspondent is not a pant of the designation given to the subject upon which he wites. For example. Jones may write regarding the - Smith 'Timber Sale. In that event. Jones's letter would be filed under the Fmith Timber Sale. I cross reference, consisting of a sheet of Yelluw paper. bearing the name .Tones and the subject designation of the case under which the correspondence from him has been filed, wruld be filed under. Jones in the Ceneral File.

\section{Traxshermang.}

Correspondence in the General File will be transferred, periodically. with the accompanying alphabetical guide cards, to units of the same size as those of the current file. The entire file from i to Z will be transferred.

Correspondence filed under designaterl subjects. but not moder desigmaterl trallsations. on ol off Sational Forests will be transferred 
periodically. by subjoets. with areompan ing guicle cards, and new guicle eards inserted in the current files.

correspondenec in designated trinstedions will he transferred as the transations are elosed. The ()flice conecrued will notify the file clerk by forwarding the transation record "ard stamped "Closed." 'The file clerk will therempon transfer the transation folder, giving it a serial number, which will be entered upon the transaction record eard and the latter returned to the Ollice. Whemerer an Oflice has need of the papers in a closed transaction. the transation record card will be sent to the file clerk. to whom it will serve both as a requisition and ats a means of locating the transaction folder in the transfer file. When a transiation folder is thus withdrawn from the transfer file. the rearel eard will be returned with the folder to the office concerned.

Thansfer cases for the Gemeral File will be labeled with the applopriate letters of the alphabet and the inclusive dates.

'Transfer eases for correspondence under designated subjects, hut not under desimaterl transactions, on or off the National Forests will be labeled with the appropriate designations and the inclusive dates.

'Transfer cases for correspondence under designated transactions on or' ofl Cational Forests will be laleded with the first and last serial numbers of the elosed transaction folders transferred.

\section{WITHMR.IW.M.S.}

The file clerk only is anthorized to lile paper's and to withdraw and roturn them to the files.

Upon the requen of Oflires or Sections the tile derk will deliver -pecifierl folders or correspondence. without receipt. In order to maintain the efficiency of the files, it is incmmbent upon any Oflice or sertion to return enrespondence and palpers promptly.

\section{W.ISIINGTON.}

The procedure pre-cribed for files and filing in. J)intridet (ofliens will be followed in Wa-hington. (2xeret that subject files will bo naintained by Districts instead of by Forests. modified from the suliject filen outlined for District Oflices to comprise merely the business landled in Washingten under the reorganization.

\section{EXAMINATION OF RECORDS BY THE PUBLIC.}

The papers on file in District and Supervisors' offices are public records. and the information contained in them should be freely imparted under reasonable safeguards to those whose interest is legitimate.

Information on file should not be given to those without legitimate interest in the matter involved. Cases have occurred in which lists of per- 
mits furnished by the Forest Service have been used to solicit business from all the permittees with the intention of subjecting them to wholly unnecessary expense.

Under no circumstances may inquirers take papers outside of the building from the files.

\section{PROCEDURE BY UNITS IN ORGANIZATION.}

\section{DISTRICT OFFICES.}

OFFICF OF THE DISTRICT FORFSTEIR.

DUTIES.

The general direction of all work of the District Offices. and upon Tational Forests within the District, and the supervision of ivork conducted in the Oflice of the District Forester.

ANnUal Estimates.

Estimates for allotments or appropriations submitted to the District Forester and by him to the Forester must furnish a practical working basis for the consideration of the proposed expenditures throughout. The estimate for salaries will be by indiriduals on the basis of present salaries. and the names of those alrealy employed should be entered. Whenever an additional employee is estimated for, it will be so stated. Estimates for expenses must not be in a lump sum, but separately by expenses of individuals, and for permanent improvements, by projects. Proposed contingent funds will not be shown separately, but will be summarized in one contingent for the District. Totals will be by lines of work so far as practicable, summarized by units in organization. The sums required for brush burning and to provide for handling additional sales and for forest planting will be estimated for in as much detail as practicable, and when approved will constitute definite allotments instead of contingents. For convenience these allotments will be made to Organization, subject to reallotment to Forest Supervisors at the request of Silviculture.

Allotment Estimates.

Estimates for allotments for the next ensuing fiscal year will be submitted on $A$ pril 1 by District Offices to the District Forester. The District Forester will submit to the Forester on May 1 allotment estimates for the District. The Forester will then make an allotment to the District from each appropriation, the allotment for salaries and general expenses inchuding a specified amount as a District Contingent Fund. and a specified amount to be used exclusively for fighting fire. 
When the District Forester is notified by the Forester of the amounts allotied to the District, he will make allotments to Ollices, Sections, and Forests. and send the Forester a statement of the allotments made. 'The I) istrict Forester will make no allotments until he is motified that the amount to he allotted is in the United States Treasury, subject to the District Fiseal I gent's requisition fol funds. Similarly, the Distriet Forester will sign no letter of authorization mnless it is covered by an allotment made by him, exept that he may sign authorizations for cooperation work when the amount to he authorized does not exeed the amount to be contributed.

A continerent will be reserved by the Forester to cover expenses for fighting fires exceeding the District Fire Contingent and other large and unforesen expenditures for which allotted funds are not arailable.

\section{Appropriation Estmates.}

Estimates for appropriations for the fiscal year following the next ensuing fiscal year will be submitted on $A$ pril 1 by the District Offices to the Inistrict Forester. The District Forester will submit on May 1 appropriation estimates for the District to the Forester. As soon as practicable thereafter the District Forester will be notified of the action taken.

\section{Promotions.}

Promotions wiil be considered only once a year, and all promotions for the year will be made on July 1, insteat of on January 1 , as specified in Regulation 1, U. B., page 31. 'The District Forester will submit to the Forester on Ma! 1 his recommendations for promotions for the year. For each promotion recommended the reasons will be stated, and the present salary. salary recommended. and the date and amount of the last promotion. if any, will be given. The increase in allotments abore I istrict estimates, rendered necessary by the annual promotions. will be made by the Forester.

\section{IAS WT.}

\section{DUTIES.}

Arice to Listriet uflicel's and to Supervisors; apploval of legal documents and correspondence; assistance to chiefs of Field Division and Special I Irents of the General Land Office. "pon request, in claims conte-ts; and recommendation of court proceerlings and assistance to Uniterl states Ittormey's. upon reruest.

ROUTINE.

ADVIrE.

Letters answering legal quentions will be approved by the District Law Officer after preparation moler his advice by the Office concerned. If the question is new. and of importance as a precerdent, 
an index card will be prepared giving the subject; the subject number according to the Century Digest Classification Scheme; the key initials of the Ottice or Section concerned; and the date of inquiry and of the answer. In answering a question the District Law Officer will sign a formal memorandum, with three carbons, one for his subject file, the second for that of the Office concerned, and the third for the Forester. 'The original will be sent to the inquirer by the Office concerned.

Memoranda should be brief, clear, untechnical, and exact in the citation of authorities. They should bear the subject designation and number. and if necessarily long. a prefixed summary in the form of a sylliabus.

Summaries will be made, given subject designations and numbers, and filed. of brief's, pamphlets. and memoranda of permanent value.

Approval of Legal Docements ate Correstondence.

Agreements, honds. contracts. permits, stipulations. and other legal documents incident to the business of any Office will be drafted in that Office, following the forms prescribed in the Legal Form Book.

The form of all timber sale contracts for more than $\$ 5,000$. bonds for more than $\$ 1.000$, and right of way permits and stipulations except those for telephone lines, wagon roads, and noncommercial irrigation plants will be approved by the initial of the District Law Officer.

Any deviation from any prescribed form will be indicated specifically to the District Law Officer. and approved by his initial in the left margin opposite the clause concerned.

The execution of all timber sale contracts for more than $\$ 5.000$, bonds for more than $\$ 1.000$, right of way permits and stipulations, with the exceptions abore mentioned. and of all documents executed by a private or municipal corporation, association, or partnerslip will be initialed by the District Law Officer in the right margin opposite the space for signature.

New forms proposed for legal documents. in whole or in part, after approval by the District Law Officer, will be submitted to the Forester for inclu-ion in the Legal Form Pook.

\section{Claims Contests.}

When hearing is ordered. Occupancy having noted on the claims index card the fact and date of litigation, changed the case designation by incerting $\mathbb{X}$ after the key initial, and given written notice to the File clerk to note on the folder that the case is in litigation with the date. the notice will be sent to Law. An index card will then $x$ filled ont (blue for mining claims and white for all other 
claims) giving the case designation with the letter $\mathbf{X}$ inserted, dates when litigation begins and ends, its nature, the original and appellate tribmals, the date of appeals, orders, ete. When litigation ceases, Law will notify the file elerk to enter the date on the folder and transmit the notice to Occupancy for further action. The letter $\mathrm{X}$ will be inserted in the ease designation on all papers in a litigated case, as notice to the mail clerk for reference of correspondence.

\section{CoUnt Cases.}

All letters forecasting legal proceedings will be initialed by the District Law Officer. When suit is recommended or begun, or arrest made. the routine will be as prescribed for Claims Contests, except that a buff index card will be used.

Bricfs and arguments in litigated cases mill not be embodied in letters. but will be prepared, transmitted, and filed as prescribed for memoranda under "Advice."

Recommendations of suit to the Attorney-General will be prepared for the signature of the Secretary of Agriculture. Correspondence with the Commissioner of the General Land Office will be signed by the District Forester. Other legal correspondence will be signed by the District Law Oflicer.

Collection of State Forest laaws.

Law will maintain, chronologically, in temporary binders under States, a file of forest lams and of other laws affecting National Forests enacted by the States within the District. At the close of each fiscal year the collection will be revierred and completed, annotated after the manner of Bulletin No. 57, the year's legislation summarized in the style of the Review of Legislation in the New York State "Library Y car Book of Legislation" for 190 ๖ and 1906, and the whole transmitted not later than September 1 to the Forester for publication.

Miscellanlous Projects and Index Carbs.

Definite tasks imposed upon Law and not included in the above classification will be recorded on cards in the manner preserilsed under "Advice." The card will bear as a subject designation the word "Miscellanerm-," followed by other necessary description and the date upon which the task was undertaken and completed. Index cards for Advice, Litigation (contesterl claims and cont cases), and Miscellancous Subjects will be filer? separately. Cards for open ases will be filed alphabetically throughout, by name, without regard to Forest. As cases are closed the cards will be filed alphabetically by names under Forests. behind a guide eard marked "Closed in current month.". At the end of the month, after being ueed for the monthly report, they will be filer in like order as closed cards.

$61045-0$ - 3 


\section{OPERITION.}

\section{DUTIES.}

The protection of the National Forests, the organization, maintenance, and field and office equipment of their personnel, and the supervision of all permanent improvement work.

Recommendation to the Forester regarding changes in the area of existing Forests and the ereation of new Forests; determination of the advisability of proposed administrative sites and recommendation to the Commissioner of the General Land Office for withdrawal of sites from entry; report and recommendation to the Commissioner of the General Land Office on claims eases; and recommendation to the Commissioner for listing homestead applications.

The supervision of special use business.

The supervision of the District Fiscal Agent, who will make and record disbursements and record receipts, will control the accounting methods of Special Fiscal Agents and Supervisors, and will keep the accounts of the District.

The maintenance of the files and other equipment in the District Oflice, and the supplying of assistance in drafting, stenography, and typewriting.

ROUTINE.

Organization.

ALLOTMENTS TO FORESTS.

Annually on April 1 a schedule of proposed allotments to Forests for salaries and general experses for the ensuing fiscal year, based on Supervisors' estimates, will be submitted to the District Forester. This schedule will show tabularly by Forests the salary and general expense allotments separately for the current year, and the Supervisors' estimates and the recommendation of Operation for the ensuing year.

When the total allotment for salaries and general expenses on Forests has been made by the District Forester, proposed allotments will be revised accordingly, and after they are apploved by the District Forester, Accounts will be notified on Form 659 of the allotments made. At the same time, letters will be prepared for the signature of the District Forester, notifying each Supervisor of the amount allotted his Forest for salaries and general expenses, and of the number, grade, salary, and period of service, of each man to be employed under appointment, and of what portion of the amount allotted for general expenses should be spent for forest planting. Accounts will then be notified on Forms 659, initialed by the Chief of Operation, to prepare for the signature of the District Forester a letter of authorization to each Supervisor for the amount allotted him for general expenses. 
As monthly allotment and liability statements by Forests are recoived from lecomts they will be somtinimed to determine whether reatjustment of salary or expense alloturents is necessary. 'The need for this selutiny incerases wh tho advance of the fiseal year.

IPRRSONXH:T.

Artion necessiry on the appointment. promotion, demotion. resignation. furlongh. snspension. dismissal. transfer, or separation of oflicers on National Foress will be initiated in Organization. on Form 6.59. and initialed by the Chief of ()peration. In case of dismissal a eopy of the chalges and the reply will accompany Form 6is. All letters to oflicer on National Forests notifying them that action in any of the above clases has been recommended. which are disciplinary in whatcter. will be sigued by the District Forester.

Finm (ian embodying proposed action atlecting the grade, assignment. or salary of any oflicer on a National Forest above the rank of Guarl. before it is forwarded to Acomnts, will be sent to the Chiefs of rilvieulums. (ivazing. and l'roducts, for initial if they concur. If they fail to enenr. action will ho determined by the Distriet

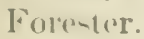

Since a card rocoud of Disuict persommel is available for reference in Aecounts. 110 and resord of the Sational Forest personnel will be maintaines in ()ranization.

FHIIIBIS LIST.

Is Statc lists of aligibles for appointment as Issistant Forest Ranger are received from IVashington, a card will be filled out with the name and addless of anch eligible and the carls filed alphabetically ly names. muler States. Copies of each State list will be sent to all Supervisors within that State and within the District, from which appointments will be recommended. Then Form (i5), requesting an appointment. is prepared, "I ppointed." and the name of the Forest will he stamped upon the correspendiug are which will be flled alphabetically by the Ftate. bahiud a gruicle card marked "A ppointed."

When an appointment is requested from an eligrible list for a State whirh falls within more than wne District, a carbon of Form 659 will be sent to the District Forestro who has juriscliction within the same state. who will make the necesary record in his card list of eligibles. As frequently as rendered necessary by the number of appointments made, revised State lists will be sent to Sunervisors.

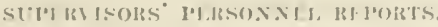

The annual personnel reports (U. B., p. 190) will be submitted on April 1, instead of November 15 as heretofore, and will be used as a basis for recommendations to the District Forester of promotions of officers on National Forests. 
MEETINGS OF FOREST OFFICERS.

With the exception of meetiugs of his own force called by a Supervisor (U. B., p. 29), meetings for the instruction of officers assigned to National Forests require the approval of the District Forester. Plans for these meetings will be prepared by Organization, and submitted to the District Forester.

\section{PLOTECTION FROM FJRE.}

Organization will consider and pass upon Supervisors' recommendations for the organization and equipment of their fire patrol, including the distribution of the permanent force and the employment of additional men during the fire season. It will also handle requests from Supervisors for allotments and authorizations for fire fighting. against the Fire Contingent Fund. It will submit for the approval of the District Forester, plans for Federal, State, and private cooperation in fire protection involving the force on National Forests.

Reports of fire trespass and negotiations preliminary to settlement will be handled in Organization. When timber or forage has been damaged, the assessment will be passed upon by Silviculture or Grazing. If just settlement can not be secured all papers in the case will be referred to the District Law Officer, with a memorandum of the action recommended.

EQU1]MENT AXD SIPPLILS FOR FOIESTS.

Forest Supervisors will continue to obtain equipment and supplies by requisition direct from the Property Clerk at Ogden. When the Property Clerk asks any District Fore-ier for further information before filling a Supervisor's requisition. Organization will conduct the necessary correspondence with the supervisor concerned, and prepare a letter to the Property Clerk. for the signature of the District Forester.

Certificates to the condemnation or loss of property upon National Forests will be initialed by Organization.

BECOMMUNDATIONS FOR AWERTISINT.

On May 1 of each year, Supervisors will recommend a list of newspapers for advertisements of Forest business during the next fiscal year. When approved. the lists will be cent to Acconnts, so that the necessary letters of anthorization may be secured, and copies forwarded to silpervisors.

ENGINHRING.

COMPLLTE PLANS FOR IMPROVEMENTS.

Supervisors will submit in duplicate to the District Forester not later than March 1, 1909, complete plans so far as practicable, covering all needed improvement work of every class on their Forests. These should 
give not merely the improvement work proposed for one year, or for a series of years, but entirely apart from the question of the time required to complete them, should show what, in the judgment of the Supervisor, would be, under present conditions, an adequate system of trails, roads, telephone lines, and other improvements, for the effective protection of his Forest, and for the full development of its usefulness. The plan should euumerate by classes the projects proposed, and should include under each project a tentative estimate of its cost and a brief statement of the need for it. Both completed and proposed projects should be shown on duplicate sets of the best maps available. Completed projects will be shown in ink of a different color from that used for proposed projects.

Annually, on MIarch 1. Supervisols will submit in duplicate a revision of the complete plan submitted the previous year.

FSTIMATE EOH IXPROYEMENTS.

Annually, on March 1. Supervisors will submit, with the complete plan above described, a detailed estimate for those projects shown on the complete plan, which are of sucle urgency that they should be undertaken during the ensuing fiscal year.

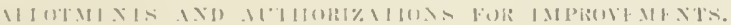

Engineering will srutinize superisors detailed estimates, from the enginering -tandpoint, and -nbmit them to the Chief of Operation, als a batis for his recommlendation to the District liorester, of the total amount reguired for permanent improvements in the District for the rnsuing ficcal reir.

When the allotments to Forests for permanent improvements are made by the District Forester. Accounts will be notified on Form 659, and letters for the signature of the District Forester to Supervisors will be prepared, informing them of the allotments to their Forests, and designating the projects approved for construction during the ensuing fiscal year. Accounts will then be notified on Form 659, initialed by the Chief of 0peration. to prepare a letter of authorization to each Supervisor for the amount of the allotment to his Forest for permanent improvement work. Enginering will then conduct correspondence with Supervisols in-

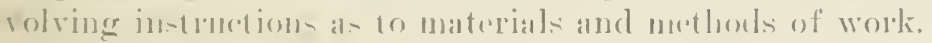

RECORD OF PRIHJECTS.

A rard record of approwed projects will be kept under Foresta one eard being fillod ont with the designation of each project. These rards will be used as an index to the sabject files, and in chereking ex-

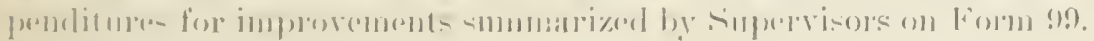

SUPS.ritSORS' REPOH TS.

Form- 25:3, received monthly from supervi-ors, will be 11 Engineering to check the progress of improvement work, and will be filed hehind the corresponding arel in the lemerd of Projects. As 
final reports upon empleted projects are received, the corresponding card in the Record of Projects will be stamped "Closed," with the date, and put behind a guide card marked "Closen," in the same file.

At the end of the fiscal year Supervisors will close in their project ledgers all accounts with uncompleted projects, and will report them in the manner prescribed for final reports upon completed projects. Work upon an uncompleted project continued in another fiscal year from that in which it was begun requires the opening of a new account in the project ledger, under a new allotment and authorization.

\section{VOUCHERS FOR IMPRONEMENT WOKK.}

Before vouchers for improvement work are certified by the Chief of Operation, they will be initialed by Engineering to show approval of the expenditures for lahor and material, and that the work has been anthorized.

DISTRIYT ATLAS.

In addition to the data received from Supervisors and from Washington, information gathered by the District Oflice and a record of the business transacted by it will be posted in the District Atlas. This data, which will be furnished to the District Engineer upon his requisition, will include the following:

Grazing will furnish proclamation maps on which are shown the classification of each Forest for the handling of grazing, according to the Forest Atlas Legend.

Operation will furnish the location of all permanent improvements constructed, adninistrative withdrawals. listed Forest homesteads. fire statistics, and all approved special uses which can be shown by the conventional signs of the Forest Atlas Legend.

Silviculture will furnish data relating to timbar sales and free use, the location of plantations and nurseries, and the general clascification of land with its stand of commercial timber, according to the Forest Atlas Legend.

The status of land, received from local Land Offices and in the monthly report of entrien of the General Land Oflice, will also be posted in the District Itlas.

It the end of each quarter. or more frequestly when justified by the importance of new recorded data, or when so instructed by the Forester, duplicate atlas sheets, showing corrections and additions posted, will be forwarded to Washington for porting. and to serve as a basis for new erlitions.

MHENAIOX.

In order to obtain the status of a given tract. the Distriet Mtlas will first be consulted by the oflice requiring the information. The District Atlas does not show changes oceurring after the publication 
of the folio, and before Jannary 1. 1909, or since the posting of the last monthly report from the General Land Otlice. If the District Atlas shows the tract to be vacant land, or that title has passed from the United States, no further seareh is ordinarily mecessary. If the tract is covered by an unperfected entry, or a withdrawal inconsistent with its reservation for forest purposes, or if other donbt exists, the necessary information must be obtained from the local Land oflice.

In such cases, Engineering will prepare. upon requisition from the Office requiring the information, a letter (Form 31) for the signature of the District Forester to the liegister and Receiver, requesting the status of the tract in question. Replies from local Land Offices will be referred by the mail clerk to Engineering, which, after posting the information in the District Atlas. will refer the replies to the Offices concerned.

DRAFTING AND LITEPRINTIN.

Engineering will fill requisitions approved by the District Engi neer for drafting of the rarions classes and for blueprinting.

All maps and other graphic records which do not constitute essential parts of the papers in any case will be filed in Engincering.

\section{OCCUPANCY.}

All index curds in rlowerl cases will follow the montine prewiber uncler Law, p. 33.

BOUNDARIIS.

The District ()ffice will inrestigate the advisability of boundary projocts either upon its own initiative or under instuctions from Washington. These studies will follow plans approved by the District Forester and he marle in accordance with the "Instructions to Boundary Man " of June 24, 1907.

Thr recommendation of a District Forester upon a propo-ed creation, addition to. or elinination from a Forest, will be accompanied by the original report. type and title maps, petitions or other nees. sary papers. a draft of proclamation (without diagram), and a letter for the signature of the Forester, "transmitting the proclantition to the Conmi-cioner of the General Land Office. If the project war proposed by a person not in the Forest Service, a letter for the signa ture of the Forester to the person ennerned. presenting the lecision of the Forester and the conclucion upon which it was based. will accompany the Distrid Forester secommendation.

The proclamation will he prepared with four copies. (One will be filed and the orieginal with three copies sent to Washington. une for the Forester's files, one for the Cieneral Land Office, and one for transmission by the General Land ()fice to the State Department with the origrinal. 
The District Forester's recommendation upon a proposed temporary withdrawal or release will be accompanied only by a title map. a description of the area to be withdrawn or released.

The District Office will be notified of final action upon any project and will take whatever action is necessary to establish the new boundary assuming control of the area added or relinquishing control of the area eliminated.

Boundary projects will be recorded on cards filed by Forests, on which will be entered the name of the Forest and project. date of withdrawal, date of examination, name of examiner, character of petitions with date of receipt, date of approval by District Forester, date of forwarding maps and reports to Forester, character and date of Forester's action. and date of proclamation.

RANGER STATIONS.

If a proposed ranger station conficts with an unperfected claim, the Supervisor's report will include the price for which the improvements can be purchased. His report will, in all cases, include a formal recommedation on Form 271, with 220 if the land is surveyed.

Upon receipt of the Supervisor's report, an index card and folder will be made, each to be filed alphabetically by name of the site under the Forest. The index card will contain the name of the Forest, the name of the site, date Supervisor's report received. date withdramal requested, and date withdrawn.

If the District Forester's decision upon the Supervisor's recommendation of a proposed ranger station is unfavorable, the Supervisor will be so notified and the case closed.

If the decision is faroral)le and if the proposed site conflicts with an unperfecterl claim, Occupancy will, if the status is otherwise clear, send all papers to Organization, which will, in cooperation with Engineering, consider the purchase of the improvements, and the price to be paid for them, and return the papers to Occupancy. If the purchase is disapproved, the Supervisor will be notified and the case closed.

If the purchase is approved, the Supervisor's letter of authorization will be increased accordingly. The Supervisor will then be instructed to secure from the claimant and forward a relinquishment and a Form $A$ youcher, giving the location of the claim and the price of each improment. When these are received, Occupaney will request the withdratral by a letter, accompanied by a blneprint of the proposed site, to the Commissioner of the General Land Oflice for the signature of the artict Forester.

When notice of withdrawal is received from the Forestr, Occupancy will send to Engineering a Form $A$ voucher for id rial, which will then be signed by the Chief of Operation and for payment. 
No patented land will be purchased in auy state, 'Territory, or District for ranger stations or other purposes without special nuthority from the Forester.

\section{CLAIMS.}

Requests for report on claims referred from Washington will be recorded and referred to the Supervisor by stamp.

Upon receipt of reports from the Supervisor and firon such experts as have examined a claim. the I) istriet Forester will prepare a letter of recommendation on Form 308 or $1+\bar{t}$ and send it to the Commissioner of the General Land Oflice. Copies of the reports will aceompany adverse letters of recommendation only.

If the Conmisioner of the General Land Office does not concur with the recommendation. the case will be handled by the Law Officer in Wishington.

When the District Forester receives notice of hearing. the case will be transferred to the 1)istrict Law Officer during litigation. If the decision of the local Land Oflice is brought before the Commissioner of the General Land Oflice by proceedings in the nature of an appeal. the case will be handled by the Law Officer in Washington.

Notices of the final action of the Department of the Interior on any elaim will be forwarded from Washington to the District Office for filing with other papers in the case.

The record of the ease will be made on plain cards. using blue for mining claims and white for all other claims. The card, which will be filed alphabetially by the name in the ease designation, should also contain the name of the Forest, also the date of the Land Oflice request. receipt of report... the District Forester's recommendation, the notice of hearing. the recision of local Jand Office, appeals, and closing of the case.

\section{SETTLEAENT,}

Application for Forest homesteads will be addressed to the District Forester, to whom will be referred applications made in error to the Forester or to a Supervisor.

Applications who-e dercriptions of the land are too incomplete for record, or which apply for orer 160 acres, or for two noncontiguous tracts. will bre returued for conertion, muless the application shows a settler's preference right under the Forest IIomestead Art.

All other applications will be stamped with the date of receipt and recorded in the Iistrict oflues tract book in the order of their receipt as shown by the post-ollice cancellation stamp. 'The envelope in which the application is received and previous correspondence will be attached. 
An index card and folder will be made for each new application. The index cards will be filed alphabetically by the names of applicants, and the folders by Forests in the order of the serial number of the application, if recorded. The index card should also contain the name of the Forest and the serial number of the application. The folders for applications returned without record, as above provided, will be filed alphabetically in front of No. 1, pending correction of errors.

Recorded applications embracing surveyed lands, or unsurveyed lands which can be described by the probable section number, will be examined as to status. The status data of the District office, including copies of any maps. will be supplemented when necessary by information from the local land office.

If the status examination shows that the tract is not vacant public land, or that an unsurvererl tract will probably be shown by survey to be land granted in prisenti to a railroad or other grantee, the application will be canceled and the applicant so notified.

If the status examination shows that an unsurveyed tract is within the place limits of any railroad or other grant in prosenti, but will probably be shown by surver to be vacant public land, the applicant will be notified that any subsequent action upon his application will be subject to defeat by the survey if the tract turns out to be land included in the grant.

If the tract book shows that the land has been examined and unfavorably reported upon. the application will be rejected uniess known changes in local conditions justify reexamination.

The District office will acknowledge applications, and in case of partial conflict will so inform the applicant by footnote.

Township plat Form 974 will be sent to the Supervisor filled out to show the tract applied for, if surveyed, or the deccription of it, if unsurveyed; the name and number of the applicant: date of settlement, if given; and the date of receipt of application.

After the Supervisor lats submitted a report on Form 110, the District Forester will, if the report shows the tract applied for is not chiefly of value for agriculture. or is needed for public purposes, reject the application and so inform the applicant in order that he may apply for another tract.

If the Supervisor's report is favorable and deccribes the lands to be listed by metes and bounds. the original field notes, three copies of which will be sulmitted, be checkerl as to sufficiency of survey, and a tracing made with fon blueprints. Descriptions of legal subdivisions will be eherked as to accorary. hut no tracing made. 
If only a portion of the land applied for should be listed, the District Forester will inform the applicant and furnish him with a description of the area approved for listing. In order that the applicant's case may be closed without delay, a letter for his signature will be inclosed so that he may indicate his intention to make entry of the area reeommended when listed, or withdraw his application. When the applieant is informed that a part of the tract applied for will be listed if he so desires, an reminder card will be filed calling the case up for action at the end of sixty days. At the expiration of this period, if no reply has been received. the applicant will be informed that in the absence of a reply within thirty days his applieation will be canceled.

As a result of the foregoing action, the application is withdrawn or eanceled, or the applicant requests that the area recommended be listeci.

Letters to the Commissioner of the General Land Otlice for the signature of the District Forester, recommending the opening of tracts to entry and noting all conflieting applications for each tract, will be prepared with three carbons, and will transmit the blueprints and field notes. which will be distributed as follows: One eopy of each will accompany the letter to the Commissioner; two copies of each will be sent to the Supervisor with two eopies of the letter to the Commissioner; one copy of the blueprint will be sent to the applicant. The original field notes and a tracing, after reference to the District Atlas, will be filed in the applieant's folder.

When the District Forester is notified by the Commissioner of the General Land Office through the Forester that a tract has been opened to entry, he will so notify the applieant.

Each.District will begin a new series for numbering the lists. commeneing with 1, and will use the number of the District as a key number. Thus, lists prepared by the District Forester for District No. (i) will be numbered $6-1,6-2,6-3$, ete.

In-tructions contained in the circular "Method of Recording and Filing Applieations moler the Act of .June 11. 1906." will be followed.

\section{SPICIAI, ESES.}

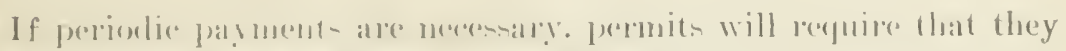
be: Inalu on the first or lifteenth day of the month.

Supervisors' Permits. - The original copy of the permit forwarded by the Supervisor will be scrutinized. If unsatisfactory, necessary instructions will be given him to correct or cancel the permit. 
District Foresters' Permits, Class " b" and "c."-Applications made in error to the District office will be referred to the Supervisor concerned. After the necessary information is obtained from the Supervisor, the District office will make final decision, issuing the permit if action be favorable, and notifying the applicant through the Supervisor in either case.

Foresters' Permits, Class "a" and "d."-Applications made in error to the District office will be referred to the Supervisor concerned. The Supervisor will send his recommendations to the District Forester, accompanied by other reports and papers pertaining thereto. In Class "a" cases these will include the map and field notes, original and triplicate copies of the Supervisor's report (Forms 964 and 578), and the District Engineer's report.

The District Forester will then prepare his recommendations and submit them with all other papers in the case to the Forester. retaining on file a blueprint of the map.

Upon receipt of a Class "a" permit prepared in Washington (which will be accompanied by an extra copy for the District office file), it will be transmitted to the Supervisor for execution by the permittee and returned, through the District office, to the Forester (see U. B., p. 57), who will approve the permit and transmit it through the District office to the Supervisor for delivery to the permittee. Class " $d$ " permits will be received and transmitted to the Supervisor for delivery to the permittee in the first instance.

Interior Department Rights of Way other than Railroads.-The District office will, upon receipt by reference from Washington of two blueprints of the map filed in the Department of the Interior, refer one copy to the Supervisor concerned for report on Eorms 964 and 578.

Upon receipt of the Supervisor's report, the District office will prepare a stipulation with four copies. The original and three copies will be sent to the Supervisor, the original for execution by the applicant and return to the District office, one copy for the applicant, one for the ranger, and the third for the Supervisor's files. The fourth copy will be filed in the District office. The District Forester will, upon receiving the executed stipulation from the Supervisor, recommend approval of the application to the Commissioner of the General Land Office.

Interior Department Rights of Way, Railroads.-The District office will, upon receipt by reference from Washington of the Commissioner's request for report with two blueprints of the map filed in the Department of the Interior, refer one blueprint to the Supervisor concerned for report on Forms 964 and 578 .

Upon receipt of the Supervisor's report the District office will prepare recommendations and submit them with the Supervisor's report to Washington, retaining the blueprint in the files of the District office. 
Upon receipt of stipulation prepared in Washington, accompanied by copies for the District office file, the applicant, the Supervisor, and the ranger concerned, it will be sent to the Supervisor for execution by the applicant and return through the District office to the Forester.

Record and filing.-In index card will be prepared for each case, and a calendar card (Form 340) for those in which a charge is made. The index card will contain the name of the Forest, but will be filed by name of applicant. Upon it will also be entered the date the application is received, the issue of permit or rejection of application with dates, and the date upon which periodic payments, if any, are due and the date and amount of atch payment with the number of the Notification of Receipt. For Class " " " and "d "permits, a duplicate of the index card will be retained in the District oflice and the original sent to Washington with the District Forester's recommendations. Since all payments fall due on the 1st or 15th, Form :30 will be filed under semimonthly guide eards in the order in which payments are due. The permittee will be notified one month before payment is due on Form 362, accompanied by Form 861. If payment is not received, the second notice will be sent fifteen days after payment is due, giving notice that the permit will be canceled if payment is not received within fifteen days. These notices will be sent to the Supervisor for transmittal to the permittee. This procedure for collections will be followed by the District Office for Supervisors'. District Foresters', and Forester's permits. Notifications of Receipt will be handled as prescribed for timber sales (see "Class A and unadrertised Class $B$ sales").

Accounts.

ALLOTMENT I.EUGER.

The District Fiseal $\mathrm{Agent}$ will keep separately on sheets (Form 14) an account with each allotment to the District made by the Forester.

The sources and clasies of entries will be as follows:

DEBIT.

In suballotinut column.

1 Fonm District Fromester's letters of allotment.) The amomis, including ronstingent funfls, orirrinstly allotted to Oflices, Siections, anu [iorests, and subseruent changes. I'prensus will he rntered in red ink.
CREDIT.

In allotment rotumn.

(From Forester's letters of allotment.) The amount oriorinally allottel the d)istrict from the given alp)ropriation, and sulosequent changes. I) rerenses will be entored in red iuk. 
In disburscment column.

Montlyly (from District Fiscal Igent's abstracls of disbursements), the total of the month's disbursements under each District allotment.

Monthly (from Special Disbursing Agents' abstracts of (lisbursements), the total of their disbursements under District allotment.

Currently (trom 'Treasury settlement notices), the amomts disbursed by the Treasury in settlement of claims forwarded by the District Fiscal Agent. (see p. 4S.)

\section{In deposit column.}

Currently (from District I'iseal $\triangle$ gent's and special Disbursing Agents' requisitions for funds), the amounts on approved requisitions. These entries will be ehecked against the certificates of deposit as receired.

Currently (from Treasury settlement nolices), the amounts disbursed by the Treasury in settlement of claims forwarded by the District Fiscal Isint. (See 1). 4S.)

For any account in the Allotment Ledger, the difference between the net District Nllotment and the total disbursements is always the amount to the credit of the District.

The difference between the net District Allotment and the total of all certificates of deposit and of the Treasury Settlement of Claims is always the amount which may still be drawn from the Treasury.

The difference between the total certificates of deposit and the total disbursements is always the total amomnt to the credit of the District Fiscal Agent and of the Special Disbursing Agents immediately available for disbursement.

The District allotment and suballotment columms of each account in the Allotment Ledger should always balance, since the District Forester will immediately suballot the money allotted to his District by the Forester.

DISPURSEMENT LEDGER.

The District Fiscal I gent will lieep separately on sheets (Form 15) for each Special Disbursing Agent in his District an account of deposits to his credit and of his disbursements. The District Fiscal Agent will also use this form for an account mudel each District allotment of the deposits to his own credit. and of his disbursements.

'The sources and classes of the cntries will be as follows:

DERIT.

(From lequisitions lassed by the District Fiscal Agent in faror of Special Disbursing $\Lambda$ gents.) The total of each requisition without regard to arruropriation.
CREDIT.

(From srecial Disbursing Agents' monthly Abstract of Disbursements.) 'The total of their disbursements.

Entries to the accounts of the District Fiscal Agent in the Disbursement Ledger will be made daily, as follows, from the Cashbook summary sheet (Form 18):

The amomnt depositer to the credit of the District Fiscal Agent uuder each District allotment.

'T'otal disbursement under each District allotment. 
The date and anomi of each Sperial Disbursing Igent is boud will be entered at the head of his arcount.

The balance in each account in the Disbursement Ledger will show, subject to deduetions for vouchers pail but not credited, the amounts in the hands of each special Disbursing Igent, and by each appropriation, the amount in the hands of the District Fiscal I gent. A trial balance of all accounts will show, subject to derluction for rouchers already paid but not credited. the total sum available for disbursement in the District.

CASHBOOK.

The District Fiscal Igent will enter on sheet (Fum 18) each deposit made to his credit in the subtrasmy.

All checks will be typewritten, using both sictes of sheets (Form 16) for carbon copies.

Daily all checks against cach appropriation will be entered consecutively, and the total of all checks against each appropriation, with its title, will be entered in the last two columns on Form 16.

Daily the total by appropriation of checks drawn must balance with the total of all cherks drawu and of all vonchers paid, before the checks are mailed.

The difference between the total deposits and the total disbursements shown on form 1 s will be entered daily as the balance.

\section{DUPLICATE CHECKS.}

For issuing duplicate checks, see Treasury Cireular No. 47 of June 25, 1908. Duplicate checks issued will not reduce the Cashbook balance, will not be included in the day's summary of disbursements, and will be recorded only by notation on the carbon of the original check.

VERIFICATION OF DIFOSITORY BILANCE.

The District Fiscal Agent will receive monthly from the Assistant Treasurer a statement of all checks paid since the last report and of the balance to his credit. This will be compared with the carbon copies of checks (Form 16), and those listed will be stanped "Paid." The unpaid checks to and including the date of the statement will be entered on sheets (Form 29) and the total subtracted from the balance stated by the Assistant I reasurer, and the result compared with the total balance from all appropriations shown to the credit of the District Fi-cal Igent on Cashbook shaet (Form 18). The District Fiscal Agent will then sign and return the form letter which accompanied the Assistant 'Treasurer's statement. 
TREASLRY SETTLEMENT OF CLAMMS.

The District Fiscal Agent will send to the Forester, for transmission to the Iuditor for the State and other Departments, all claims which under the regulations must be settled by the Treasury. He will number and record in sequence on Treasury settlement sheets (Form 1i) all claims forwarded for settlement, placing the appropriate initial ("P," Portland; "S," San Francisco; "O," Ogden; "M," Missoula; "D," Denver. and "A," Albuquerque) before the claim number.

The District Fiseal Agent will receive through the Forester notices of the settlement of claims by the Treasury, which he will enter on Form 17, and post to the proper accounts in the Allotment. Ledger and on the Allotment and Liability cards (Form 21).

D.ILY DISBURSING PALANCL.

A daily statement of disbursing balance (Form 543) will be rendered to the Chief of Operation.

ALLOTAENT AND LIAEILITY RECORD.

A record of all alloments for salaries, expenses, improvements, and cooperation, and of all liabilities and disbursements thereunder, will be kept on Forms 19, 20, and 21.

The District Forester's allotments to offices and sections for salaries, general expenses, cooperation, and contingent funds, and all changes therein, and to Forests for salaries, general expenses, improvements, and cooperation, and all changes therein, will be entered on allotment cards (Form 21).

These entries will be made only from Forms 659. initialed by the District Forester.

Allotment cards will be filed under two main guides-one for offices and sections, alphabetically by name of office, and by sections under offices; the other for Forests, alphabetically by name of Forest.

AUIOIMENT CARDS FOR OFFTCES AND SECTIONS.

There will be for each Office and Section a salary allotment card, a general expense allotment card, and, when cooperative work is carried on, a cooperative allotment card.

The Salary Allotment Card (Form 21) will show the total salary allotment, current salary payments, total salary payments to date, changes in liability, net liability, total disbursements and liability, changes in allotment, and allotment balance. The total of the individual salary liabilities from individual salary cards will be shown as the total liability of each Office or Section. 
The allotment balanie will be aflected by changes in allotment and by transfers of individuals by the Distriet Forester, and by orders of the Secretary of Agrieulture aflecting salaries. Net liability will be affected by changes in the salary status and by transfer's of individ uals, and will be reduced by the amount of each salary payment:

Entries of salary payments to -alary allotment cards will be daily by totals from the individual salary cards (Form 19).

Individual sulary Curd. (Form 19) will be filed alphabetically behind the Salary Allotment Card of each Oflice or Section. These will show the salary status of each individual, the monthly salary parments to him. and the total payments for the fiscal year to dite. On each card an individual liability will be entered from form 659. equal to the salary of the individual for the period of his assignment, whether for all or a part of the current fiscal year.

Enitries from Form 65? will be rerified by comparison with order of the Secretury of $\mathbf{A g r i c u l t u r e}$ affecting salary status.

salary payments will be entered from pay-roll and salary vouchers.

The individual liability will be decreased by each salary payment and affected by all orders of the Secretary of Agriculture affecting salary status of the individual.

The General Expense Allotment Card (Form 21) will show the allotment for general expenses. and changes therein, disbursements (daily totals) against this allotment moler individual letters of authorization. changes in liability, total disbursements and liability, and allotment balance.

Allotments anl changes affecting them will be entered from Form 6.5. Letters of anthorization and changes aflecting them and dishursements will be entered daily by totals from the individnal expense cards (Form 20).

Individual Expense Cards (Form 20) will be filed alphabetically behind the dllotment carrl of each office and section for general cxpenses. These will show for each individual the number and form of each letter of authorization and each change affecting it, current and total disbursements. and net liability.

Entries relating to letters of anthorization will be taken from Form 659 and rerified by comparion with letters of anthorization. Disbursements will be entered from vouchers.

The Cooperation Allotrumt Cards (Form 21) will show the allotments, liabilities, and disbursements for cooperation work. The procedure in making entries will be identical with that provided for entries upon the salary and genrral expense allotment rards. This allotment reeord will be -mpplementerl by an individual record of each project under each ronperation allotment card.

(i) $101-0 \mathrm{OS}-4$ 
There will be for each Forest allotment cards for salaries, for 4reneral expenses, for improvements, for fire when fire occurs, and for ooperation when cooperative work is carried on.

The Salary Allotment Card (Form 21) will show the total salury allotment. current salary payments, and total salary payments for the fiscal year to date, and the balance of salary allotment. The totals of salary payments will be entered from column A, Form 99, and will include Supervisors' certification numbers on rouchers. No salary liability will be established.

Individual Salary Cards (Form 19) will be filed alphabetically hehind the Salary Allotment card of each Forest. These will show the salary status of each individual, the monthly salary payments to him, and the total payments for the fiscal year to date.

No individual salary liability will be established.

Entrics from Form 659 will be rerified by comparison with orders of the Secretary of Agriculture affecting salary status.

Salary payments will be entered from pay-roll and salary vouchers.

When a salary payment is to be charged partly to the Salary Allotment and partly to the Improvement Allotment, the amount will be shown separately and the total included on the Inclividual Card in the total payments to date.

The General Expense Allotment Card (Form 21) will show the allotment to the Forest for general expenses and all changes therein, Iiability under letters of anthorization, disbursements against this liability, net liability, total disbursements and liability, and allotment balance.

Entries will be made from the District Forester's letters of allotment and letters of authorization, and from column B, Form 99, and will include Supervisors' certification numbers on vouchers.

Individual expense cards will not be maintained.

The Improvement Allotment Card (Form 21) will show the allotment to the Forest for permanent improvements and all changes therein, liability under letters of authorization, disbursements against this liability, net liability, total disbursements and liability, and allotment balance.

Entries will be made from Form 659 and from column C, Form 99, and will include Supervisors' certification numbers on vouchers.

No cards for individual improvement projects will be maintained.

The Fire Allotment Card (Form 21) will be used when expenses for fire are incurred, and will show the allotments and disbursements only.

The District Fiscal Agent, on receipt of approved vouchers for fire expenses, will transfer from the Operation Fire Allotment Card 
to the Forest Fire Allotment Card the amount necessary to cover the roncher's. Disbursements will be entered from the vouchers when the allotment is trinsferred.

The Cooperation Allotment Card (Form 21) will be used for cooperative work in the same manner as preseribed under Oflices and sections (p. 49).

TRANSFER OF SALARY CARD.

When any member is transferred from one Oflice, Section, or Forest to another. his individual salary eard will be transferred from the file of the unit he leaves to the file of the unit to which he is transferred. In order that the year's record of expenditures may be complete for the unit he leaves, a record of the parments to him will be made in red ink on a card (Form 19), which will be marked "Substitute Card," filed behind the enrrent cards, and cross referenced to the file to which the permanent card has been transferred. $\Lambda$ substitute card will be used when a member is transferred to another District, and the permanent eard will be sent to the District Forester concerned. The Individual Salary Card of a member separated from the Service will be filed with the substitute cards until the end of the fiscal year, when it will be filed alphabetically in a transfer file.

VOUCIIER AND CERTIFICATION NUMBERS.

The voucher numbers will be entered in the second column on Allotment and on Indiridual Expense cards (Forms 21 and 20), and in the first column on Salary cards (Form 19). The certification number's entered on vouchers by Forest Supervisor's will also be entered in the second column of Forest Allotment cards.

PROOF OF ENTRIES.

Daily the Allotment eards and Individual Salary and Expense cards on which entries have been made will, after entry, be returned to the files, with paper markers in front to distinguish them from the cards not affected by the day's entries.

Ifter all disbursements have been entered, the entries on the Individual cards will be totaled and entered on the Allotment cards (Form 21), except in the case of entries on Individual Salary Cards and Salary Allotment cards for Forests.

Since the total current salary payments to an officer on a National Forest will be entered on his Individual Salary card, but may be charged partly on the Salary Allotment card and partly on the Improvement Allotment card of the Forest to which he is assigned, the total salary payments on the Individual Salary cards will exceed the total salary parments cliarged on the Salary Allotment card by the 
total of salary payments charged on the Improvement Allotment card.

Entries on Individual Salary cards for any Forest will be totaled and compared with the total of salary disbursements entered from columns $A$ and $C$ of Form 99 on both the Salary and Improvement Allotment cards.

After all disbursements have been entered the entries on the Individual cards will be totaled and entered on the Allotment cards (Form 21).

The day's entries of disbursements on the Allotment cards will be totaled and the totals compared with the total disbursements for the day as shown by the Cashbook. After the correctness of the day's entries has been thus verified, the entries on both the Individual cards and the Allotment cards will be checked and the paper markers removed.

Disbursements of each Special Disbursing I gent will be entered in the Allotment and Liability record from the rouchers submitted monthly, and the entries will be proved in the same way as the District Fiscal Agent's daily disbursements by comparing the total amounts entered with the total of the abstract of disbursements which aceompanied the vouchers.

A trial balance of the Liability Record may be taken on any date from the summary cards, and will show the total disbursements, net liability, and allotment balance for each Office, Section, and Forest, and for the District.

The sum of disbursements, net liability, and allotment balance for each Section, Office, Forest, or for the District will show the total allotment for each.

MONTILY LIABILITY AND FINANCIAL STATEMENTS.

A trial balance of the Allotment and Liability Record (For'm 159) will be prepared in triplicate, one copy filed and one copy submitted to the District Forester on the 1st of each month and one enpy to the Forester. Salaries, general expenses, and improvements will be shown separately for each Office, Section, and Forest.

The fact that Form 159 has been prepared will be shown on each summary card by inserting in red ink opposite the figures nsed the date of the report.

Each Chief of Office will be furnished with a copy of that part of the monthly statement concerning his Office, and the Chief of Operation will receive a statement of the expenditures and allotment balances for each Forest.

A Financial Statement (Form 279) will be prepared in duplieate on the 1st of each month. One copy will be submitted to the District Forester and one copy to the Forester. 
APOLNTHET RECORDS.

Form 659 will be wised as a memorandum for the Distriet Fiscal Agent of all desired changes aflecting salary status and will serve as the basis for the preparation, with two carbons, of letters for the signature of the Forester to the Secretary of $\Lambda$ grieulture (Forms $211 \mathrm{~A}$ to $211 \mathrm{M}$, or special letters), recommending the action desired. The original and one carbon will be forwarded to the Forester. The second copy will be filed alphabetically in Accounts in a waiting file until the desired action has been taken. Copies receired of letters changed in Washington will be substituled for copies in the waiting file.

As orders of the Secretary of Agriculture affecting salary status are received they will be eompared with the entries already made on salary cards and the date of appointment and other supplementary facts entered on the salary cards.

Cards (Form 272). filed alphabetically, will be used instead of Individual Salary cards for record of temporary laborers. From them a monthly report on the departmental form will be prepared in triplicate with copying ribbon, one copy submitted to the District Forester, and the original and one copy submitted to the Forester. Forms 19 and $2 \pi 2$ will constitute the record of the District persomnel.

P'ERSONNEL INDEX.

Since Salary cards (Form 19) will be filed by oflices, sections, and Forests, an alphabetical index of the District persomel will be kept on cards (Form 23). All changes in assignment will be entered on index cards (Form 23) from Form 65?.

RECORD OF ABSENCES.

Absences from duty will be entered on Form 24 from Form 143 for all members whove salaries are paid under Forest allotments. from Form iS5 for all members whose salaries are paid under Office or Section allotments, and from furloughs by the Secretary of Agriculture for all members of the District personnel.

REQUISITIONS FOR FUNDS.

'The District Fismal Agent will make his requisitions for funds in duplicate on Form 612. and will forward the original to the Forester. retaining the erpy in a waiting file until he receives a certificate of deposit from the subtreasury.

A requisition for funds (Form 281) from a Special Disbursing Agent will be entered in the Allotment and Disbursement Ledgers, initialed in the lower left-hand corner, and forwarded to the Forester, provided it does not exceed the difference between the amount of the Sperial Disbursing A trent's hond and his balance on hand, nor his allotment balance as Supervisor. 
TREASURY NOTIFICATION OF WARRANT ISSUED.

When the District Fiscal Agent receives notification of a warrant issued in his faror, he will compare and file it with the copy of his requisition for funds.

On receipt of a notification of a warrant issued in favor of a Special Disbursing Agent, it will be compared with the amount charged under the corresponding requisition in the Disbursement and Ailotment Ledgers, and the notification forwarded to the Special Disbursing Agent.

CERTIFICATES OF DEPOSIT.

The District Fiscal Igent, on receiving from the subtreasury a certificate of deposit to his credit, will verify it with the corresponding requisition and warrant, and make the necessary entries in his Cashbook (Form 18), and in the Allotment and Disbursement Ledgers (Forms 14 and 15).

HANDLING OF YOUCHERS FOR DISBURSEMENT.

As vouchers are received, each will be dated, given a receipt number, and recorded on cards (Form 260).

Audit.-Every voucher will be examined for compliance with the Fiscal Regulations of the Department of Agriculture, and the Decisions of the Comptroller of the Treasury.

All salary and purchase vouchers to which certification has not been made that the articles have been received in good condition or the services have been rendered, will be returned. When properly certified, vouchers will be audited against the Allotment and Liability cards to determine whether the expenditure is anthorized, and covered by the balance available.

Every Form $\mathrm{A}$ and Form 4 voucher covering the purchase of nonexpendable property must be accompanied by an invoice and a signed receipt (Form 939) which will be sent to the Property Audito", after the number of the paid roucher is entered in the lower left-hand corner.

If a voucher covering the purchase of nonexpendable property is not accompanied by Form 939, this form will be filled out in triplicate, the number of the paid voucher entered in the lower left-hand corner, and the three unsigned copies forwarded to the Property Auditor.

Vouchers (Form BF) for advertising will be examined for compliance with the Secretary's letter of authorization and the sworn statement of rates.

Payments to temporary laborers for services of one day or more will be recorded on salary cards (Form 272), from Form 143 and from vouchers Forms $\mathrm{A}$ and 4. 
From vouchers (Form 4) the use of transportation requests will be checked against cards (Form 199). and the use of mileage will. be entered on cards (Form 266).

Vonchers will be sent to Chief- for certification in envelopes with a list of receipt numbers of the vouchers inclosed. I carbon of this list will be retained until all vouchers recorded on it have been returned, when it will be destroyed.

So far as possible, vonchers will be certified the same day, and will be returned with the list in the envelope in which they were received. Touchers withheld will be noted on the list by the eertifying officer, which will not be clestroved until the retained vouchers are also received.

Revieu.--As vonchers are received after certification, they will be reviewed for the correctness of andit, to determine that certification is compitte, and that changes recommended by certifying oflicers do not confliet with the Fiseal Regulations and the Decisions of the Comptroller. and that the amount to be paid is clearly shown on the voncher. Touchers should not be reviewerl by the person who audited them.

Payment.-Daily, after review; vonchers will be sorted by appropriation and given voucher numbers. The number of the check drawn in payment will be entered on each voucher. Daily, the total of all check.. compiled from the checks themselves, must agree with the total of all vouchers paid. before the checks are mailed.

Only when accounts contain a large number of separate charges, as, for example, transportation accounts, will Form 484 accompany the checks, for identification.

The vouchers, with the corresponding checks. enrelopes, and remittance cards. will then go to the District Fiscal I gent, who will scrutinize the roucher and check and sign the latter.

After vouchers are paid, Invoices and Receipts (Form 939) will be detached and sent to the Property Auditor, and the necessary entries will be made in the Allotment and Liability record, Analysis of Format Disbursements, Toucher liegister. Tiecord of Absences, Abstract of Disbur-ements; and Littlefield Report. The Form 99 accompanying vouchers will be filed separately under Forests by Supervisors certification numbers.

AXII,YSIS WF IUREST HSI:TRSEMHENS.

The vouclers for all expenditures under Supervi-nes allotmention

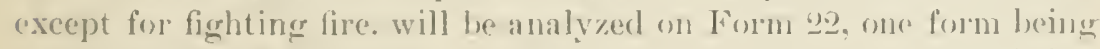
used for each Forest. and one line for each volcher, entries being marle from Form 90.

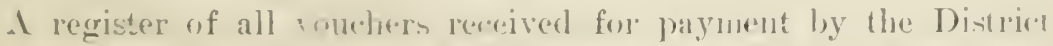
Fiscal igent, except pay roll- (Fom 143). will be kept on rald 
(Form.260). A card will be used for each payee. one space for each roncher, and the eards filed alphabetically by name of payee. Form 143, which will constitute a supplement to the Voucher Register. will be filed by offices, sections, and Forests. When a voucher is received, its description and amount, the date of receipt, and the Supervisor's certification number will be entered on the card. When a voucher is returned for certification or correction. or is sent to another Fiscal Agent for payment. the date of action and reason will be entered. When a voucher is paid, the roucher. check. and file numbers, the date and amount of payment, and the ardires to which the check was mailed, will be entered.

LITTLEFIELI REPORT.

'This report will cover for each appropriation for a fiscal year payments from July 1 to September 30 of the following calendar year, and will be submitted to the Forester annually, not later than the 20 th of October.

Daily payments will be entered from Touchers upon cards, Form 278 for salaries, and Form 250 for all other disbursements. 'These cards will be filed alphabetically under the appropriation from which the payment was made and by the following elasses thereunder: Salaries; Travel, Station and Field Expenses: Stationery; Furniture; Apparatus; Instruments and Laboratory Material; Express; Freight; Telegraph; Telephone; Rent: Gas and Electricity; Fuel; Printing and Binding; Miseellaneous Supplies and Services, Equipment, Books, Machinery, etc.

A voncher paid in part from one appropriation and in part froni another will be entered on separate cards and the cards filed under the proper appropriation and class. The items on a voncher will, when necessary, be entered separately on eards under the different clasces. Reimbursement Vouchers, Form 4, will always be classed as "Travel, Station and Field Expenses." Transportation Requests settled by payment to railroads will be entered in red ink on the "Travel, Station and Field Expense" cards of the member who used the request.

A summary card will be kept in front of each class under each appropriation, and the total of the daily entries on the individual cards will be entered upon the summary cards, and the total of the summary cards compared with the total payments to date on the Abstracts of Disbursements.

Monthly parments will be similarly entered from the vouchers submitted by the Special Disbursing $I$ gents, and annually Treasury Settlement of elaims will be similarly entered from Form 18.

At the end of each year the entries on each card will be added and the totals entered on Littlefield Report sheet- (Departmental Forms) 
in duplicate. One copy of the Dapartmental Form and all carrls (Forms 250 and $27 s$ ) will be sent to the Formeter.

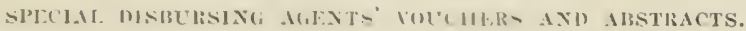

The District Fiscal Agent will instruct Special Disbursing Agents to forward, not later than the fifth of each month, vouchers for the disbursements of the previous month, accompanied by an Abstract of Disbursements. These rouchers will be reviewerl for rompleteness of certifiention. and to determine whether those wrering nonexpendable property are supported by Invoices and signed Receipts. The Invoice and Receipts which accompany the ronchers will be sent to the Property Anditor. Where Invoices and Receipts are necessary, but not attached, they will be filled ont in triplicate and sent unsigned to the Property Auditor.

A record of the services of one day or more of all temporary laborers will be entered on Salary Cards (Form 272). Disbursements will be entered from the summary (Form 99) accompanying the abstract. on the Allotment and Liability Record Cards (Form 21). and will be proved under the procedure established for the proving of the entries of the District Fiscal Igent's disbursements. (See Proof of Entries. p. 51.)

The total dishurements will be entered from the Abstract of Dishursments in the Disbursement and Allotment Ledgers.

The disbursements by Special Disloursing Agents, except disbursemont: for fire expenses, will be entered on Form 22, from recapitulation sheets (Form 9:4). 'The Forms 99 will then be filed nuder' Forests by supervisors certification numbers. Vouchers will be filed by voucher number with the correponding Abstracts of Disbursements until the end of each quarter, when they will be forwarded to the Forester: with the corresponding Account Current, not later than the twentieth day of the month following the last month of the 'pliarter.

\section{RECEITS ANO LIFH NIR.}

Receipts.-Receipts from all sources will be paid to a designated United States Depository for each District. A Form 861 will be prepared by the Supervisor or Ranger concerned, for each transaction involving payment, with one copy in the case of grazing permits and with two copies in all other cases. The original will be given to the payee for transmission with his remittance to the Depository. One copy will be retained by the Supervisor or Ranger. The third copy will be sent to the District Forester. For grazing permits the Supervisor or Ranger will send in a copy of Form 762 instead of Form 861.

Daily, from Form 861, the Depository will record remittanees on an Ab-trate of Receipts (Form an), of which two copies will be 
furnished to the District Fiscal Agent, with a copy of the certificate of deposit covering all entries on the Abstract of Receipts for the same clay. The Abstracts of Receipts will bear the numbers of the corresponding Certificates of Deposit, and at the end of each quarter the totals will be summarized on sheets of the same form.

The District Fiscal I gent will prepare a Notification of Receipt (Form 26) with two carbons, for each remittance, one carbon to be filed alphabetically as an index to receipts, and the other carbon to be sent with the original card to the Office concerned.

\section{REFCNDS.}

ReFunds to depositors of money deposited in excess of the amounts due will be refunded on vouchers (Form A) in accordance with the Act of March 4. 1907 (34 Stat., 1256), the instructions in the Use Book (p. 150), and the Fiscal Regulations of the Department of Agriculture. Refunds will be made in the manner prescribed under "Handling of Vouchers for Disburscment" (pp. 54 to 55 ).

Analysis of receipts.-From the Abstract of Receipts each deposit will be entered separately by classes under Forests on sheets (Form 27) which will be kept in a loose-leaf binder. Each day's entries will be ruled off. totaled, and proved by comparison with the total on the Abstract.

At the end of each month the total receipts for the month by classes will be entered from sheets (Form 27) on Forest Receipts Cards (Form 28), separate cards for each Forest being used, for each of the following classes of business: Grazing, Special Uses, Timber Sales, Timber Settlement, and Timber Trespass.

From the Forest Receipts Cards the total receipts of each month for each Forest will be summarized on a Forest Summary Card (Form 28). The total receipts of each month for each class of business for all Forests will be summarized on a Class Summary Card (Form 28), and the total receipts of each month from all classes will be summarized on a District Summary Card (Form 28).

Analysis of refunds.-Vouchers covering refinds will after payment be entered, separately by classes under Forests, on sheets (Form 27 ). At the end of each month the total of all entries of refunds during the month will be proved by comparison with the total on the Abstract of Disbursements. From the shects (Form 27) the totals for the month will be entered on the Forest Receipts cards (Form 28). From the Forest Receipts eards the totals will be summarized on the Forest Summary, Class Summary, and District Summary cards (Form 28) in the same manner as prescribed for receipts.

Comparison of receipts. - The record on the Summary eards (Form 28) will be completed monthly by entering the net receipts and the 
amount and percentage of increase or decreate in gross receipts as compared with the same period of the preceding fiseal year.

Report of receipts and refunds-Reccipts-i Report of Receipts will be compiled in duplicate at the end of each month, giving, by Forestis and by clasers, the gross receipts for the month and the total gross receipts to date. Form 27 will be used. and two lines will be need for each Forest. one for current and one for total receipts. The monthly and total receipts to date by classes for all Forests and the grand total of receipts for the District will also be shown. Two copies of the Report of Receipts will go to the District Forester not later than the fifth of each month. and he will immediately submit one copy to the Forester.

licfunds.-I Report of Refunds, similarly prepared on Form 27 , will go on the same date to the District Forester. who will submit one copy to the Forester.

ABSTRACT OF DISBURSEMENT.

Daily disbursements will be entered from paid rouchers upon the Ib-tract of I)isbursement (Form 15t) in duplicate. The totals of these entries must coincide with the total disbursements for the day as shown by the Cashbook.

ICCOYXTS C URRFNT.

The District Fiscal I gent will render a quarterly Ascomt Current of di-bursement and receipts. The Account Current (Form 389), with abstracts (Forms $15 t$ and 25 ) and the corresponding vouchers, will he mailed to the forester not later than the 20th way of the month following the last month of the quarter.

TRAXSIORTATIOX REQLESTS AND MIIEAGE BOHKS.

Trunsportation Requests will be forwarded to the District Fical I gent upon the recommendation of the Distriet F'orester. 'The District Fiseal Igent will keep a reerord of tramsportation requests receiverl and will iswe them upon repune- from offices on Form firis. I card record (Form 199)). filed alphabetically, will be kept for eath person 10 whom transportation requests are issmed. As transportattion-request coupons are receiverl they will be entered on the card.

The vouchers of transportation wompanies will be andited against the entries on Forms 199, which will be wheelked als paicl. 'The I)istricet Fiseal A gent will pay transportation vourhers only for requmets of which he has record.

Ifileage Boolis, purchased on transprutation requests. will be rw-

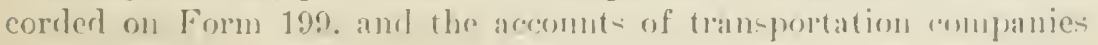


will be audited as above. A record of all mileage purchased (Form 266) will be kept for each person who purchases mileage, on which will be recorded the use of mileage as reported on Form 4 vouchers. Unused mileage will be sent to the District Fiseal Agent, who will credit the individual concerned on Form 266, and forward it to the transportation company for refund.

Transportation Refunds. - A refund by a transportation company will be remitted to the District Depository and will be credited to the appropriation under which the disbursement was made.

IDFNTIFICATION CARDS.

The District Fiscal Agent will have a personal identification card prepared for the signature of the District Forester, and will procure the necessary telegraph identification cards, for all members to whom letters of authorization are issued, and for such others as the District Forester may designate. The numbers of personal and telegraph identification cards will be recorded on the Individual Salary card. The District Fiscal Agent will recover all identification cards from member's leaving the Service.

AUTHORIZATIONS FOR ADVERTISING.

As lists of newspapers recommended for the advertisement of National Forest business are received from Organization, they will be incorporated in letters requesting the necessary authorizations to the Secretary of Agriculture for the signature of the Forester. As the authorizations are received in duplicate the original will be filed and the duplicates forwarded to the Supervisors.

\section{MAINTENANCE.}

QUARTERS.

The accountability of the Chief of Maintenance for property in the District Office will follow the routine prescribed under "Forest Accountability." in Service Order 15 (Field Program. May, 1908). He will be responsible for the efficieney of the janitor service, and will report to the District Forester any violation of rules for the safeguarding of quarters and property, including the Service Order that only safety matches be used in quarter's ocenpied by the Service. He will be charged with the disposition and efficiency of the messenger force, and will see that rounds for the collection and delivery of papers are made at regular intervals during the day. Messengers making these rounds must not be called off for special errands. When a messenger is sent out of the building he will report to the Chief of Maintenance before leaving. Messengers will not be assigned to clerical work. 
INAL AXD FILES.

The handling of mail and of the files will follow the routine prereribed under General Procedure, pages 17 to 30.

FQUIPMENT.

The Chief of Maintenance will maintain, through refuisition on Form ti6s. on the Property Clerk at Ogden, a sufficient stock of stationery ant oflice supplies for use in the Distriet Oflice. which he will distribute under requests on Form 995. Requisitions on the Property Clerk will be prepared in duplicate, and one copy filed in a waiting file, to be nsed in checking articles received.

Requi-itions (Form 66S) for instruments and field supplies for use by members of the District Office will be made ont in rluplicate. initialed by the Chief of the Ollice concerned, and both copies sent to the Clise of Maintenance. who will be responsible for obtaining the desired article from the Property Clerk.

Under an annual allotment to Maintenance, a letter of anthorization will be issued by the District Forester to the Chief of Maintenance to cover. in cares of entergency, small miscellaneous purchases of stationery and oflice supplies, the rouchers in payment for which will be approved by the Chief of Operation. The Chief of Maintenance will purchase no article carried in stock by the P'roperty Clerk at Ogden. and under no circumstances will he purchase instruments or field equipment.

STENOGR.APEIY AND TYPEWRITING.

Is additional stenographers and routine clerks are needed in any part of a District Oflice. application will be made to the Chief of Maintenance. who. so far as practicable, will supply the need from his trained force, which will be kept constant by new appointments.

The stenographers and clerks permanently assigned to any Office or Section will be limited strictly to those necessary to maintain the current routine peculiar to it. Miscellaneous typewriting and stenographic work temporary in character, or not requiring the services of one person throughout each day. will be done by the fores concentrated in Maintenance for that purpose. When additional stenographic help is supplied by temporary rletail from this force the transcribing will be done in Maintenance, and the assignment will terminate as soon as the material is delivered.

Typewriting not involving dictation will be done in Maintenance upon requisition (Forn 161). The olservance of the following rules is necestary for economy in this work:

No manuseript will be presented for typewriting until it has been so carefully reviser that the necescity for editing it in a scratch copy is obviated. 
Botanical names. technical terms, and names of persons, towns, mountains, streams, etc., will be plainly written and correctly spelled. When tables are included the form of tabulation will be indicated.

Papers already filed under one subject will not be copied merely for filing under another subject, when a cross-reference sheet would answer every necessary purpose.

Material containing corrections on the copy and intended for the printer or for filing, but in such form that it can be easily and correctly read, will not be clean copied.

\section{SILVICULTURE.}

DUTIES.

The supervision of the sale and free use of timber on National Forests, except final decision in sales above the prescribed limit, of planting, and of silvical work.

Federal, State, and private cooperation in forest management and planting.

\section{ROUTINE.}

\section{Timber Sales.}

CLASS A AND UNADVERTISED CLASS B SALES.

Upon receipt from the Supervisor of the first duplicate Letter of Transmittal (Form 861), it will be checked for conformity with instructions (U. B. pp. TS-79), for correct computation, and to determine if the prices are consistent and not below the approved minimum rates.

The data on the first Letter of Transmittal will be entered upon a white Timber Sales Record Card (Form 615), which will be filed under Forests alphabetically by purchaser. The Letter of Transmittal will then be stamped "Recorded" and placed in the Reminder File in the Office of Silviculture. This file will be examined weekly and the Supervisors notified of cases in which payments are three weeks late. Subsequent Letters of Transmittal will be filed without record in the Reminder File.

Upon receiving original and duplicate of the District Fiscal Agent's Notification of Receipt (Form 26), the amount paid will be checked against the amount due, as shown by the Letter of Transmittal, and the amount paid and date of receipt entered on the Timber Sales Record card. The original will then be forwarded to the payee and the duplicate to the Supervisor, who, after entering the date and amount of the deposit on the corresponding Timber Sales Record Card, will send the duplicate to the Ranger concerned. The Letter of Transmittal wil] then be filed in the case folder. Shoulder the Notification of Receipt reach Timber Sales before the Letter of Transmittal, the data will be entered on a Timber Sales Record Card and completed on receipt of the Letter of Transmittal. 
As Cutting Reports ( Form s:0) atre lecived they will be compareal with the Timber Sales Record Carl for errors in entries brought forIrat from the last report, and for the correctness of the rates. All calculations will be checked and the information regarting the progress of the sale closely scrutinized. The date of the report, quantity of each class of material cut, and total value of the eut since the last report and to date. will be entered on the Record card. 'The total value of the cut to date will be compared with the total of deposits to guard against cutting in excess of payments.

ADVERTISED CLASS B SILES.

The application and report will be examined for aceordance with the instructions in Circular SM of April 22, 1905, and with instructions to the Supervisor as to price. amount, period, and other conditions. Special care is necessary to insure conservative culting, that the estimated stand to be left is suflicient: and that the plan for marking agrees with the policy for the Forest and the type.

The carbon of the Notice of Sale will be cheeked, with particular attention to the period allowed for submitting bids, the location of the cutting area, the estimate, the price, and the deposit required.

I salmon Timber Sales Record Card will be filled out and filed with the cards for sales of other classes.

If a Letter of 'Transmittal is received covering the deposit to accompany the bid of a person other than the applicant, the data will be entered on a Timber Sales Record Card. Other Letters of 'Transmittal and Notifmetions of Receipt will be handled as mder "Class $\Lambda$ and Unadrertised Class B Sales."

'The published Notice of Sale (Form 935) will be checked with the carbon previously received from the Supervisor, and filed as a reminder against the receipt of a copy of the contract and of the bond. When these are received, the data already entered on the 'Timber Sales Record Card will be checked. If the contract is awaded to another than the applicant, a new card will be filled out.

Cutting Reports will be handled as outlined under "Class $A$ and Unadvertised Class B Sales."

If the Supervisor has allowed advanee cutting (See Field Programme, August, 1207), the copy of application will be reviewed and it will be determined from the 'Timber Sales Record card whether the necessary deposit has been made. If the deposit has not been marle, the Supervisor will be notified by wile.

\section{Class C SALEg.}

The application will be examined as mnder "Advertised Class I3 sales," and if approved a blue Timber sales Rirerd Caml will be filled out and filed with the cards for sales of other classes. 
Letters of Transmittal and Notifications of Receipt will be handled as under "Advertised Class B Sales."

Ifter approval of application and receipt of deposit to cover advertising, a Notice of Sale will be prepared with two carbons, the original signed by the District Forester and. with one carbon, sent to the sipervisor.

The published Notice of sale will be checked with the carbon retained. with particular attention to the period allowed for submitting bids, the location of the cutting area, the estimate, the price, and the deposit required, and then filed in the promise eard box under the last date given for receiving bids.

The envelopes containing bids will be stamped with the date of receipt and filed unopened in the safe by sales, under the date of opening. Bids will be opened on the day following the last day for receiving bids, and the Supervisor notified of the names of bidders and the amount of each bid. If the award is made to another than the applicant a new 'Timber sales Record Card will be filled out.

A contract will then be prepared with four carbons. One copy will be filed in the case folder and the original and three carbons will be sent to the Supervisor, who will have the original and one carbon executed by the purchaser and return them to the District Office. Ifter the District Forester has approved both copies the duplicate will be forwarded to the purchaser through the supervisor and the original filed in the safe. The signatures and dates of execution and approval will be entered on the carbon retained.

When the contract is returned. executed, the data on the Timber Sales Record Card will be checked and deposits mate by unsuccessful bidders will be refunded, as provided on page 54 .

Cutting reports will be handled as under "Class A and Unadvertised Class B Sales."

If applications for advance cutting are allowed, the duplicate copy will be approved and sent to the applicant through the Supervisor. If adrance cutting is allowed, and the sale awarded to another than the applicant, the Supervisor will be notified by wire to suspend operations.

For proposed sales which exceed the limit fixed by the Forester, the Supervisor's report with the map and a copy of the application will be forwarded to the Forester by the District Forester with his definite recommendations. After the Forester has authorized the sale it will be handled by th. District Office under the rontine prescribed above.

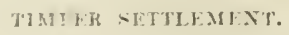

Supervisor's Permits.-The duplicate Letter of 'Transmittal will be checked and the data recorded as provided under "Class $A$ and Unadvertised Class B Sales." ning a white card (Form 615) 
stamper " "Timber sotlement," which will be hiled muler forents with the eards fore Timber sillen. The letter's of Thammital, the Notifications of liereipt, and the Cutting Reports will be handled ats meler "Class 1 and Enadrertioced Clatss lisales."

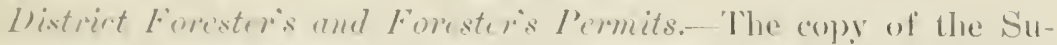

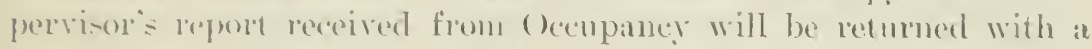
drafe of the requirements for the timber settenent in the permit or -ripulation, and a signed letter of instrutions to the supervisor. The eate will be entered on a white eard (Form 615), stamper " Thin-

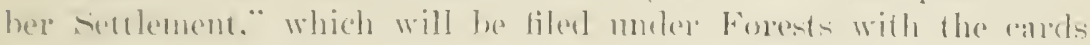
for timber sales.

C'utting report- will be handled as under ". Class 1 and Jnadver:iserl Clan-13 sales,"

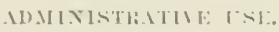

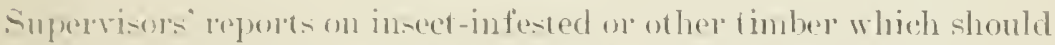
be di-posed of through administratire nee will be acted upou in the

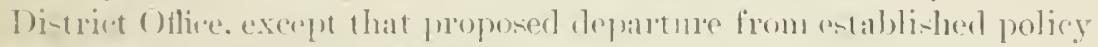
will be sulmitted to the Forreter.

Administrative use by sale will follow the routine of Class C sales, or. if without charge, of District Forester's Free Use Permits.

FILE CSE.

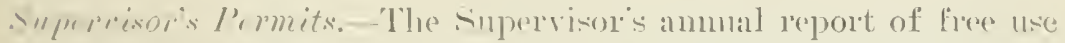
bu-iness will be carefully scrutinized and the quantity of each class of matrial and total value userl will bre antered on the summary card (Form 6110 ) as timber calt.

District Forester's Prrmits. Then an applieation for a Free Coe Permit i- i-sted. a white card (Folm (i15) stamperl "Free Use," will be filled ont and filed muder Forests with the cards for timber sales. If the primit in refuserl, the applinant will be so informed throngh the -mpervinos.

Cutting Report-will he handled as under *. Class 1 and Unadren-

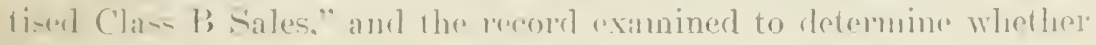
the total yuantity ent exerest-that fixerl in the permit.

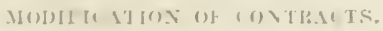

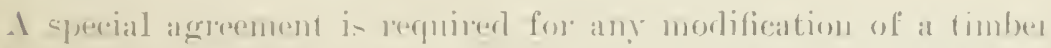

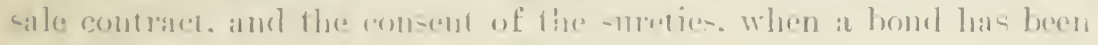
given.

Exten-ion of time willent ehange in the othere comelitions of the:

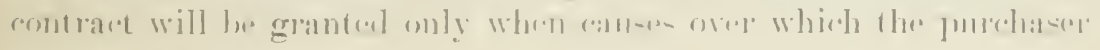

(i104- M- : 
had no control have maroidal,y delared his operations. When the purchaser is responsible for the failnre to remove the timber in the time specified, it will be determined before the extension is decided upon whether stumpage rates should be increased or other changes made in the conditions of the contract.

When a contract is modified to postpone brush piling, a bond will be required unless it acrompanied the original contract.

\section{CANCELLATJON OF CONTRACTS.}

Contracts will be canceled only by the District Forester, and after the Supervisor has reported fully upon the condition and location of the cuttings. If the cancellation is by mutual agreement, an application executed by the purchaser and approvet by the District Forester is necessary. If the cancellation is enforced, the District Forester will send a formal notice of cancellation to the purchaser through the Supervisor.

TIMIIR JRESPASS.

Upon receipt of Timber Tre-jass Report (Form S65) and a Proposition of Settlement (Form (65:3). the Supervisor will be notified whether the settlement offered is satisfactory, and the case recorded on Form 618. which will be filed under the Forest alphabetically by name.

Form s61 will be handled as under "Timber Sales-Class A and Enadrertised Class B Sales."

If legal action is necessary, the case with accompanying papers will be referred to the District Law Officer for action. No statement to the trespasser of proposed legal action will be made except with the approval of the District Law Officer.

SAIVILT. PERMITS.

Suproisor's Permits. - The papers received will be reviewed for conformity with the instructions in the circular "Special Uses-Sawmills." of September 25, 1907.

Is soon as action is taken, Form 619 will be filled out and filed under the Forest alphabetically by name of perinittee.

If a rental is charged, a duplicate copy of Form 619 will be filled nut as snon as the agreement has been executed and approved, and "eferred to Occupancy, where the receipts of payments will be followed up.

District Forester's Permits.-Except that a permit and bond will he prepared and approved in the District Office, the routine will follow that prescribed for "Supervisor's Permits." 


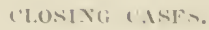

When any case in rlused the card will be stamped " Closed," the date of closing entered. and the card placed in the current file. under" the Forest. behind a guide ard marked "Closed." At the end of each month, after the cards ane reviewed for the monthly summary, the cards in closed cases will be sent to the File Room as menolanda to transfor the case forlder's to the closed file. UTon thrir retrun, the card- will be filed alphabetically by name, under Forests. in two series. those for cases approved during the curent fiscal year being separited hy a wuich card from those for cases approvert in any precediner year.

SLMMARY OF TIMBER SALE RECORDS.

A summary (Form (ifi) of the timber business will be kept for early Forest. and the cards filed in front of all other record cards for each foret. It the end of each month the quantity of each class of timber sold and cut and the value of all timber sold and cut during the month will be entered upon the summary card.

It the end of each fical year the summaries by Forests will be totaled and entered mpon a smmmary card for the Distriet. which will be filed as the first card in the current record file. The timber cut in free ure and the total cut for the year will be entered. for each Finpet. on Form 616 .

ESTIMATES.

If the estimate of total stand received from any Supervisor materially changes former cstimates, the annual cut prescribed for the Forest will be modified accordingly.

Not later than March 1 of each year the maximum annual cut and the policy with regard to sales and free use will be determined for each Forest, the Supervisors instructed accordingly, and this data entered on Form 622.

STUMPAGE RATES.

The minimum stumpage rates approved for each Forest will be revised annually not later than March 1, the Supervisors instructed accordingly, and the rates entered on Form 623.

MABKING RULI:S.

General marking rules for important forest types will be perfected as rapidly as possible. All general marking rules will be considered for revision not later than March 1 of each year. Every notice of approval of timber sale applications sent to a Supervisor will be accompanied by a letter on marking, supplementing the general marking rules and emphasizing those of particular importance in the sale in question. 
RECONNOISSANCE STUDHES.

Estimates and descriptions by sections will be made on Form 322, and township maps and estimates on Form 323. When a study is finished, a complete set of these forms and a copy of the report will be sent to the Supervisor, with the necessary instructions.

FIELD COST OF TIMBLR S.LES.

The annual cost of timber sales on each Forest will be considered with the amount of timber sold and cut to determine whether the cost has been excessive.

Federal Cooperation.

INDIAN OFFICE.

Cooperative work on Indian Reservations will be conducted under the agreement of .January 22, 1908. since this provides that all costs will be borne by the Indian Ollice, projects should not be undertaken, except in emergency, mut funds have actually been made arailable to cover the cost of the work. This necessitates in each case the preparation in the District Oflice of a letter to the Commissioner of Indian Aftairs, for the signature of the Forester, outlining the work proposed and estimating its cost.

Since all timber sales on Indian Reservations require the approval of the Commissioner of Indian Iffairs. the papers in each proposed sale will be sent to the Forester for approval by the Commissioner. After a sale is approved it will, so far as the laws and regulations affecting Indian Reservations permit, follow the rontine of Class C sales on National Forests. No timber sale on any Indian Reselvation will be recommended until its legality has been determined by the District Law Officer.

OTIMER COOPERATION.

This cooperation varies so greatly in seope and character that it has no runtine common to it as a whole. The essential points are that the correspondence leading to this cooperation and the reports upon it be transmited through the Forester, who will sign the agreements. but that the work itself be handled by the District Office. The recommendation of new projects should always include an estimate of cost, which, when rifling. or when the importance of the work justifies it. may lo bonene wholly by the service.

Sitate and Private Cooperation.

STATE COOPERATION.

Letters to State oflicials suggesting cooperation in forest management or transmitting formal agrecments, and reports of investigations and recommentations for action by the State will be prepared 
in the Distriet Otliee and sulmuttert. With one earbon, for the signature of the Forestex. who will also sign the anderments.

PIUATE COOIREITION.

Igrecuents for cooperation in fores management with private owners will be approwed by the District Forester, and all correspondence regurding it will be handled by the Distriet Ofliee. When a proponed project involves a radieal eteparture from existing policy or an inerease in the Distriet foree the Distriet Forester will submit the application for such cooperation, with his recommendations, to the Forester for derision.

Requests for prirate cooperation will be satisfied by advice hy letter when possible, or by field examination if considered necessary. alter formal applieation has been made on Form 704 . in accordance with the terms of Cireular 21 .

Reports upon cooperative stulies with private owners will be prepared in aceordance with the standard outline. Reports on the practice of forestry on private lands will be mate on Form 216.

since extra coprien of reports upon cuoperative studies are often necled to meet requests for advice. at least two extra copies of each report will be fiter with the correspontence in the ciatse folder.

I card inder will be kept in which applications for cooperation involving field stuclies will be filed alphabetically by name of applicant, and subequent steps recordent.

IPI..NTINi.

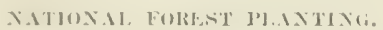

Upon receipt of three copies of each Supervisor's annual Planting Report. including a revision of the Five-Year Planting Plan extended for one year (U. B., p. 168), an annual planting report for the District will be prepared which will include a revision of the Five-Year Planting Plan for the District extended for one year. This report and revised plan will be submitted to the District Forester not later than February 1, and a copy will be sent to the Forester. Each Supervisor will receive as instructions an approved copy of the Planting Plan for his Forest.

The annual Nursery Report, submitted in duplicate by those Supervisors having nurseries. will be examined to determine the stock available for the next year's operations. An outline of the experimental work to be carried on at the nursery and a statement of the stock required to carry out FiveYear Planting Plans on those Forests supplied from each nursery will be sent each Supervisor concerned. Upon receipt from the Supervisor of three copies of a revised Five-Year Plan for his nursery extended for one year and based upon the stock required. one copy will be approved and returnerl. 
The originals of these reports will be filed as a whole and the duplicates divided and filed by subjects. The statistical reports submitted with the Supervisor's annual report on planting and the nursery, sced. and stock reports will be filed chronologically by stations.

\section{COOPERATIVE PLANTING.}

Assistance in forest planting will be given under the terms of Circular 22. Ipplications should, so far as possible, be satisfied by letters of advice, transmitting the suitable planting circulars and lists of dealers upon application.

Where a cooperative field study is advisable, the applicant will be furnished with Form 728 and Form 861 filled out to accompany his deposit. Planting plans based on field study will be prepared in accordance with the instructions in "Planting Plan Studies and Reports" of June, 1908. One copy will be sent to the cooperator and at least two extra copies kept in the case folder. Studies of established plantations will be reported in accordance with the instructions in the "Plan for Study of Forest Plantations" of June, 1908.

Cooperation in planting with other branches of the Federal Government or with States will follow the routine prescribed for State and Federal Cooperation in forest management.

The Forest Service will furnish stock only for purely experimental planting, and in such cases annual reports of results will be required.

A reminder card record will be kept of all correspondents who plan to do commercial planting, in order that cards (For'm S91) may be sent them later for reports on their plantations. When correspondence indicates that planting has already been done. the caris will be sent at once. Then returned. they will be filed under species, alphabetically. by name of owner. The card record will be reviewed not later than March 1 , and owners of plantations concerning which new data is desirable will be asked to supply it.

Data upon forest planting outside National Forests, inchuding species planted. results, and brief notes on site conditions, will be entered on "5" by 8" cards, which will be filed under States by counties. Cross references will be made to all reports on plantations within each ('ounty.

\section{Silvics.}

The men in charge of experiment stations will report directly to the District Forester, but the Supervisor will be consulted in the choice of experimental areas within his Forest. Should other use of the land be proposed by the Supervisor or by any Office, final decision will be made by the District Forester.

Copies of reports upon experimental stations and of annual silvical reports from Supervisors which contain important information 
or which propose ratical ehanges in policy or the institution of important studies will be sent to the forreter.

L.1I:RIRJ.

Upon receipt of books from Washington the ared (Form 185) will be signed and returned, and the subjert and anthor cards filed alphabetically in the card catalogue.

The receipt of periodicals will he recorded on Form 1 of the Department Library and the periorlical-kept in a binder or box next to bound rolumes of the same periodical. When a volume is complete, it will be sent to $\mathrm{Wa}^{\mathrm{a}}$ hington for binding.

When a book is loaned. a charge card (Form 172) will be signed by the borrower. the date entered. ant the card fited alphabetically by anthor. When the book is returnerl the date will be entered over the signature of the borrower and the charge card returned to the book pocket. Books needing rebinding will be sent to Washington and the fact noted on the charge cart.

The file card charges will be examined on the first of each month. and those who have harl books more than a month will be notified.

$$
\text { (IR.I\%ING. }
$$

DL“TES.

The supervision of grazing busines, under existing regulations and the prescribed allowances, periods. and rates.

ROTTINE.

GiRAZIXg I'I RMITS.

AUTIIORIZATION.

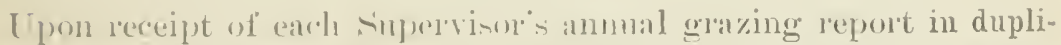
cate, a -mplementary report will le prepared, also in duplicate, ap)proving or modifying the Supervisor's report, and the original of each forwarded to the Forester.

Upon receipt of the Authorization in duplicate for each forest, it will be entered on the Inthorization Record Card (Form (40), the duplicate filed, and the original sent to the Supervisor with the neeesary instructions. The Authorization Reened Cards will be litert alpluabetically by Forests.

\section{ADVERTISING.}

As Grazing Authorizations are forwarded to Supervisors, instructions will be given, where the number of permits justifies it, to publish in one or more lowal papurs anthorized by the secretary of I gricul. ture. a notice to the public that the allowaneres periods, and lates l'on the Fores enecrued have been establisherl and that full information

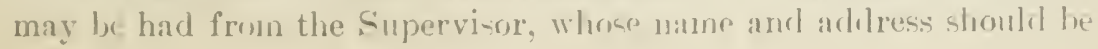


giren. Forms $\mathrm{BF}$ and afil should accompany the insurtions. I note. "Adrertisement authorized "will be made on the Anthorization Card.

Vouchers for advertising before heing approved for payment will be compared with the Anthorization Card to determine whether the publication was authorized.

MOTICE OF APPROTAI.

As duplicate notices of approval of grazing applications (Form 762) are received from the Supervisor, they will be examined for clerical errors and compared with the $I$ uthorization Record to determine whether the season, rates, and fees are correct. If mistakes are found, the Superrisor will be so informed. Should the error lie in the calculation of the grazing fees. the Supervisor mill be notified on Form 859, the correct calculation being noted in the lower left-liand corner of the card.

After examination the notices will be recorded upon the Grazing Record (Folms 621 and 256 ). which will be filed under Forests. alphabetically, by name of applicant. The eards for five-year periods (Form 256) will be remored from the filc each year at the end of the period covered by the Grazing Anthorization and filed with the cards for the following year.

Upon receipt of an amended or corrected notice it will be reviewed. and if correct the Grazing Record Card will be changed aceordingly. the notice being then sent to the file room.

Upon receipt of a supplemental notice. subsequent to the issue of the first permit, the routine will be the same as for an original notice, except that cross-reference will be made on the original card.

Upon receipt of a letter or notice canceling an application previously approved and recorded. the Grazing Record will be stamped "Canceled." and filed as before.

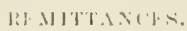

Upon receiving from Acomuts original and duplicate copies of the Notification of Receipt-. the amomut paid will be checked against the amount due and the remittane entered on the Grazing Record Card. If the amoment of the renituance is incorrect it will be checked agrainst the notice and if still found to be incorrect a pencil note indicating the excess or deficit will be marle upon the original Notifieation. Both copies of the Notification will then be sent to the Supervisor who will send the original to the permittee. Exoess payment will be refunder upon reeceipt of the duplisate of the garamg permit. (See Refunds. p. it.)

VERIFICATION.

Upon receipt of the duplicate grazing permit (Folm 656 ) it will be compared with the grating record card. If the permit is in 


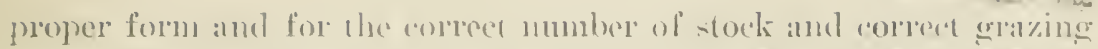

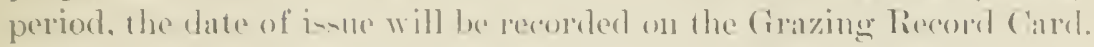

Tpon receipt af a supplemental perumit issued for stock alrealy permitted to grime lut which has been purchased, it will be checked

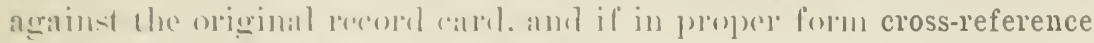
entry will be made on the original card and a new card written for the supplemental permit.

When a permit is canceled the Grazing Record Card and the duplicate permit will be stamped "Canceled."

Within a reasomable time after payments are due the delinquent applicants will be listed from the record cards and a copy of the list forwarded to each Supervisor with the request that he take steps to have payment made, or in case the applicant wishes to have his application canceled, to so notify the District office.

PRIV.TL: I.IXISS.

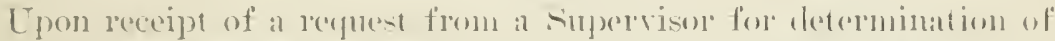
the title to private lands which it is desired to nse as the basis for a free grazing permit. a lis describing the lands by legal sublivisions will be prepared and refered to Operation. Upon rotum of the list

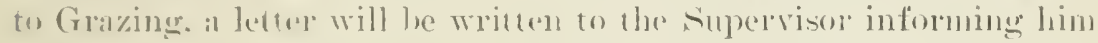
of the status of the lant and giving lim any further instructions necesily in the "isc. When a duplicate grazing permit which has been issued on account of the use of private land within a Forest is received it will be recorded on a card (Firm $f(1):$ ).

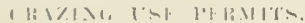

It is within the authority of the Supervisor to issue all grazing use permits which are in accordance with the provisions of the regulations. But permits for pastures exceeding 320 acres or at a lower rate than 4 cents per acre must not be issued until authorized by the District Forester.

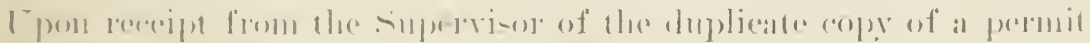

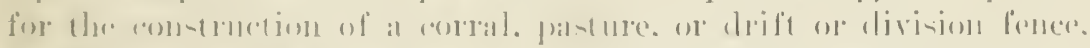

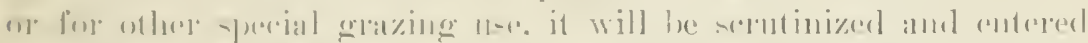

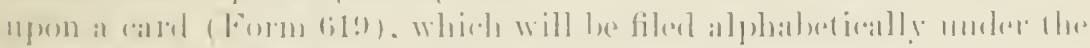

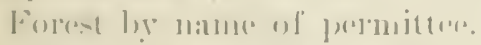

In all a rase (x)

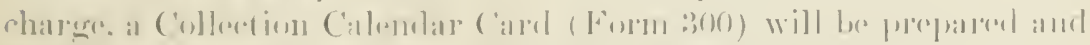

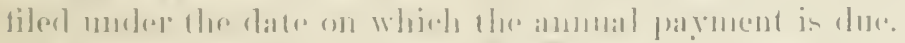

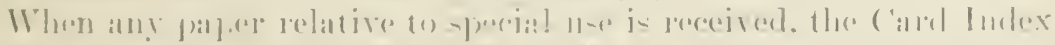

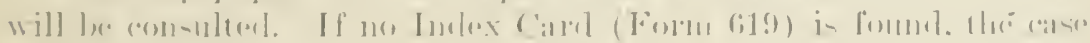

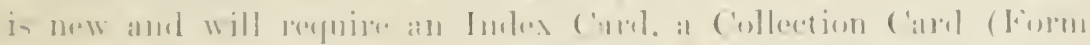

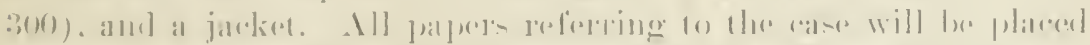

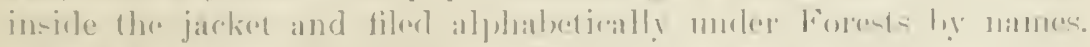
IT] 
the date of the letter elosing the case noted upon it in red ink. The Galendar Card will then be destroyed. The Index Card will be noted with number of closed transfer file containing the case, and then placed in the Closed Index file.

PAYMEXTS.

On receipt of the duplicate permit, the payment due will be entered on the back of the Index Card, left column. When a payment is received. the amomnt will be entered in the right column and in red ink. The parment will also be cheeked as paid on the Calendar Card, which will then be placed in front of the "unpaid "guide card. The payment will also be checked on the notification letter in jacket.

'The Calendar Cards for all parments due on the 1st and on the 15th will be filed behind separate guide cards.

NOTIFICATION.

The Calendar Cards will be examined at regular intervals, and one month before parment is due Form 362 will be filled out and sent to the Supervisor for transmittal to the permittee, after having been compared with the Index Card to determine that payment has not been made. If payment is due Form 362 with two earbon copies will be filled out. A letter of transmittal (Form 861), with one carbon copy. will be written and the transaction noted on the Calendar card. which will then be placed behind an " umpaid" guide eard. The original Form 362 and the letter of transmittal will be sent to the Supervisor for forwarding to the permittee, with carbon eopy of Form 362, stumped "Supervisor"s File," attached. The other carbon copy of Folm 362 will be filed in the District office.

If payment is not received within ten days after it is due a second notice will be sent in the same manner as the first notice. If no payment is made the case will be closed.

\section{TRATSEERS.}

Upon receipt of application in proper form, signed by the person who made original payment, requesting the transfer of funds either to the credit of a permit on inother Forest or to the credit of another person a cross reference will be made on the record card and the District Fiscal $A$ gent notified of the transfer. The Supervisor, or Supervisors, concerned will be informed of the transfer and instructed to make the necessary changes on their records and to issue amended or new permits.

\section{REITXNS.}

liequests for refunds which are sent in error to the District oflice, will be referred to the supervisor eoncerned for report and recommendation. If the request for refund is approved, the Supervisor will be so informed and a Form it roucher prepared for the signature 
of the person to whom the refund is to be made will accompany the letter. The amount of the refund and the date of the voucher will be noted upon the record card.

When the voucher is returned signed, it will be compared with the record cark, on which will be entered "Checked," with the date. The roucher will then be approved by the Chief of the Otlice of Grazing and sent to Accounts for payment.

If the request is disapproved, the Supervisor will be so informed with reasons.

\section{Trespass.}

Uyon receipt of a trespass report (Form S56) from a Supervisor, it will be recorded on a card (Form 618), which will be filed alphabetically by Forest and name of trespasser. The Chief of Grazing will then examine the report and accompanying papers and approve or disapprove the Supervisor's recommendations and prepare a letter for the signature of the District Forester, notifying the Supervisor of the action taken upon his recommendation and of the amount which will be required in settlement for damages. All receipts for payments will be sent in the treepasere at onee through the sirpervicor, and when payment in full has been made a letter will be sent to the tre-par-int. throngh the supervisor. closing the case.

All action or correspondence leading to settlement of a trespass case will be followed up by use of a promise card. If payment is made when due. the card will be removed and the case closed as before outlined, but if parment is not made, a letter will be written to the supervisor, instructing him to give the trespasser a definitely stated time in which to make settlement or show cause for not doing $\rightarrow 0$ and the fromi-e card will be moved ahead to this date. If at the expiration of the time the case hats not been settled and the Superviol dom not report mitigating circumstances, it will be referres to the Ial Offieer for action.

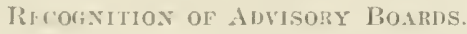

Applications for recognition of Advisory Boards not submitted through the Supervisor of the Forest concerned will be referred to him for recommendation.

Upon reecipt from at Sinpervisol of an appliention for the recognition of an disi-ory Board, accompanied by a li-t of the members of the 1 -moriation. and a copy of the constitution and by-laws. the rece. ord = of the Oflie will he axamined to determine whetlues the member-hip rompri-es a majonity of the permittees for the partiontar celass

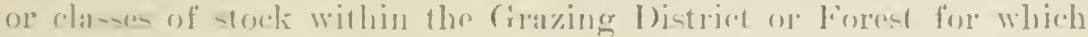
perengnition is rerpumeterl. 
If approval is recommended, and if the membership of the Issociation constitutes a majority of the users of the Grazing District or Forest, and the constitution and by-laws contain the necessary provisions. the Iscociation will be recognized by a letter addressed to its Secretary and signed by the District Forester, a copy of which will be sent to the Forester and to the Supervisor concerned, with a letter to the latter instructing him to cooperate with the Board in accordance with the Regulations.

The title of the Association, manes and addresses of its officers and the members of the Idvisory Board, and the Grazing District or Forest for which recognition is granted will be entered on a card which will be filed by Forests.

If the membership of the Association does not constitute a majority of the nsel's of the District or Forest, or if the constitution and bylaws do not contain the necessary provisions, the papers will be returned to the supervisor concerned, who will be instructed to advise the Association of the requirements.

If the Supervisor recommends the disapproval of an application, the Secretary of the Association will be so advised and informed that a perior specified will be allowed the Association in which to show cause why it should be recognized. A promise ard will bring the matter up for attention at the end of the period specified.

If appeal is filed within the period specified. all papers will be forwarded to the Forester for final decision.

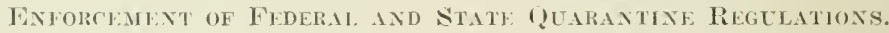

Lyon receipt from the Forester of a statement of quarantine or inspection work to be conducted by the Bureau of Animal Industry during the grazing season the District Forester will communicate with the B. I. I. District Inspectors, requesting information regarding the quaruntine or inspection regulations to be in force during the season. and the Forests to which they will apply.

Whan this information is received the supervisors concrirted will be informed of the name and address of the District Inspector in charge and will be instructed regarding the regulations to be ir foree and to cooperate with the oflicese of the Burean of Animal Industry, rendering them the necesiary assistance and furnishing them with a list of the permitees and all other information required.

The same routue will be followed in regard to State quarantine regulations, exeept that if they enflict with the regulations of the Burean of Animal Industry the matter will be submitted to the Forester before isung instructions to Supervisors.

The enforecment of Federal or State quarantine rogulations will not be undertaken by the Forest Service except in cooperation with the 13. A. 1. or State official in charge. and Supervisors will in all cases be furniched with definite instructions for their guidance. 
Upon receipt of recpuests for the entoreement of State or Federal quarantine regulations which conflict with Forest interests, or of requests from a state oflicial which conflict with the regulations of the Burean of Inimal Industry, the Distriet Foreter will endeavor to secure a modifieation. If this ean not bo sermed, the matter will be submitted to the Forrster for decision before fintl instruetions are issterl 10 stupervisors.

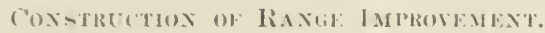

All projeet for range improventent will be approved by Giazing before construrtion is anthorized. The Chief of Grazing will inform the Distriet Engineer of his approval or disapprovil of such projects by a memorandun. The relation of Grazing to pernament range improvement work will be adrisory only, and the ofliee will unt be charget with its expention.

Kilfixg of Predatory Aximas.

Applinations for the appointment of (xuards or Rangers to serve a- hunter. will bu referred to Grazing for recommendation. The Chief of Grazing will signify his approral or disapproval of such appointment by a memoramelum to Operation or may mitiate re-

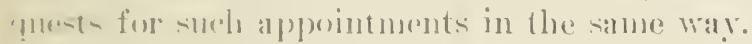

All monthly reports of the number of predatory animals killed will to handled in Grazing and retained in that office until report to the Initrict Fore-ter hat been made. The progress and eflect of each hunter"s work will be arefully noted and necessary recommendations for the tran-fir. furlough. or separation of hunters marle to Operation.

\section{Natioxil Gibe [riserves.}

When a fiame Precror is prochamed. Crazing will prepare a lettro to the secertary of Iericulture for the signature of the Forester. cmborlying complete regulations, specifying the game animals to be protected and those which may be killed; the conditions under which any animals may be killed and the permits necestry ; rectrictions grorruing the carrying and nise of firearms, and all other essential cronclition-. L pon return of the resulations approved by the Sereretary. they will lo filer in the District Oflice and full instructions grven the supervione concerume, including anthority to have the regurlations arlvertioerl and printerl, in poster form.

\section{Fovisints.}

Cpon remipt of a complaint it will be retermined if the complainant i- a promittes anil whethes reports and correspondener contain reforene to thre cause of his complaint. If the complaint 
can be satisfactorily adjusted from the Office, a letter will be written to the complainant and a copy sent the Supervisor.

All complaints concerning which the Oflice has no positive information will be referred to the Supervisor, with instructions to take neccssary action if it is within his field, or to report fully, a promise card being made out to insure attention.

Upon receipt of a Supervisor's report and recommendation definite instructions will be given him and the complainant informed of the action to be taken.

Should prompt adjustment of the complaint be impossible, on the basis of the Supervisor's report, the case will be investigated by the District Office.

APPEALS from SUPERISOR's Grazing DeCisions.

Upon receipt from the Supervisor of appeals, answers, answers in rebuttal. or other papers required by the regulations, the District Forester will make decision and will inform the appellant and the Superrisor accordingly. Should the appellant appeal from the decision of the District Forester he will be given ten days within which to present his appeal to the Forester, through the District Forester, who will transmit it with accompanying papers to the Forester for final action.

\section{Cooperatior Agreemints.}

Upon receipt of a copy of any cooperation agreement which has been entered into by the Forest Service, the Chief of Grazing will talie such action as is necessary to carry out those provisions of the agreement which refer to Grażing.

\section{PRODLCTS.}

\section{DETIES.}

Studies to increase the utilization of National Forest timbers within the District, including the investigation of markets and wood-using industries. the compilation of lumber prices. the collection of statistics of forest products, the testing of National Forest timbers, and the computation of results.

The determination, independently and in cooperation with private owners, of preservative methods applicable to the timbers of the District and rendering assistance in their application to private owners and to officers on National Forests; the supervision of all treating plants operated by the Forest Service, within the District.

ROUTINE.

WOOD UTILIZATION.

Market studies and studies of mood-using industries, made ontside* of National Forests, will be under the immediate direction of the Chief of Products. Similar studies made on National Forests will be 
under the direction of the Supervisor and the general supervision of the Chief of Products.

Monthly equotations of lumber prices foum linms in the principal

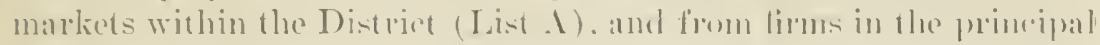
and secondary marlicts (List 13). will be aseraged and formarded,

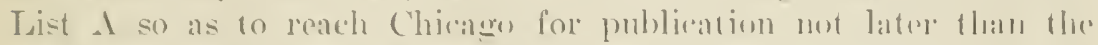
sixth, and List $B$ so as to reath Denver mot later than the fourth of

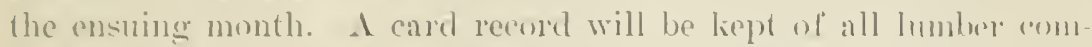
panies and wood-using industres. and as lapiolly as pussible ("oun-

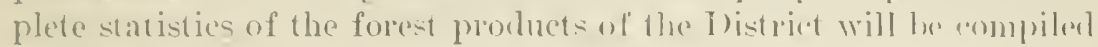
and maintained.

All timber testing laboratories within the I)istrict will In under the supervision of the Chief' of P'roducts. 'The methods of lasting. of record. and of report will follow Ciremlar 38. "Instructions to Enomeers of Timber Tests." except that monthly and sperial reports will be submitted to the Chief of Products in diplicate. of which one copy will be submitted to the Forester. On the basis of the monthly reports of the engineers in charge. monthly statements will lu prepared and forwaded to cooperators in timber tests. ropies of which will be submitted to the Forester. Riorguisitions for all computation meeder in District Oflices will be made upon the Chief of Products. who will fill those within the capacity of his computing force. and forward the others, with the data to be computed, to Washington, for computation and return.

Fo far as practicable. computing of the following clasies will le dome by the District computing force:

Checking sale books, planimeter work. statistical compilations. computations of entimates from valuation surveys, and computation= of volume and height measurements. Computation entailing the $11-8$ of diflirult formular will be fully explained. and the person for whom the work is done should keep in close touch with it thromelinut.

A fild by specie will be kept of all stand, growth, volumm, and -trengrh tables. both computed in the I)intrict and furnishrel linm Wa-lington, and copies issued, on reruest.

ITOMI) I'RESTRTATH.N.

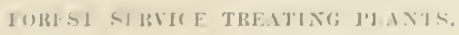

Plants owned and operated by the Forest Service for the preservative treatment of timber for use by the Forest Service on National Forests, and for cooperative experiments in the treatment of timber for private use will be under the direction of a designated Supervisor, to whom the Engineer in charge will report direct. Cooperalive experiments in timber treatment will be paid for by the conperator, on the ba-in uf actual en-t plus 10 per rent for maintenance aurl -mpervicions. 
(OOPERATIE TREATING PIAXTS.

Pant- privilely owned but operated by the Forest service, in cooperation with their owners. to determine practicable methods of preservative treatment, will be in charge of an Engineer, who will Jeport direet to the Chief of Produets. The cost, inchuling the salary of the Engineer in charge. will be rleflayed by the cooperator.

111 proposed rooperative agreenests and plans for work nnder then will be submitted to the Forester for approval.

Engineers in charge of treating plant - will record timber treatments on Forms 35-39. They will -ubmit at the end of each month a summary of work accomplished. giving the quantity and classes of timber treated. the preservativen noed. and an itemized statement of the cost of tratments. Copies of these reports will be submitted to the Forester by the Distriet Forester.

It the end of each month. Jepurts with two carbons, on each piece of conperative work in timber treatment. will be prepared on the basi- of rejorts submitted by the engineers in charge. 'The originals will be sent to the cooperator. by the District Forester, who will submit copies to the Forester.

Engincers in charge of treating plants will kecp a lecord of all timbers, prescrvalives, and othel supplien received at the plant (Forms 36 and :3s) : of the details of treatment (Form :35) : of the total expenses of operating the plant (Forms $: 97$ and 39 ) : and a

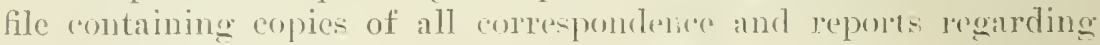
the plant.

\section{FERIOHC REPUIRT TO THE FUIENTEF.}

The I)istrice Forester' will submit a monthly report to the Forester lesting with the larger questions sutled during the past month, with those which inmediately confront the District organization. and with the general pureress and condition of forest matter's in the District. Statistial staments, corered by the reports hereafter described. should not be included.

Inmmally on April 1 the District Furester will submit to the Fore-ter allotment estimatrs and recommendations for promotions for the next ensuing year. and applopliation estinates for the year following the next rusuing yant.

The following reports will be made to the District Forester, and a copy of each submitted to the Forenter: Reports for which a date is spreified will be mailed to Washington on that date. Reports -pecified merely as monthly will be mailed to Trashington not later than the fifth of the month. Reports sperified merely as anmal wili the malled to Washington on July 1\%. Wrakly. from all offices, effi-

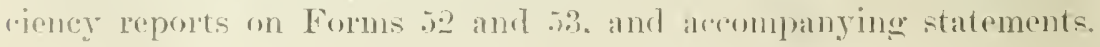


Letir (momthly).-A brief statement of new lesal questions of importance arising or likely to arise in the Distriet. and a brief report of progres: a tabulation by lorests of claims contests by class of elaim, and of court cascs (with the nature of the case) pending. begm, compromised. abandmed. concluded. appealed, or removed, with the mane of the tribunal. the nature of the conchusion (for or against the Government) and the acreage and amount of damages in controser-y, rlemanded, secured, and lost, respectively.

Fir (annual. bec. 1).- I report for the preeding fiscal year. giving by forests and by totals for the District the mmoner of fires of each class, a. b. and c: the number separately of fires set by locomotives. lightning, and campers. of incendiary fires, ete.; the total acreage burner over: the total acreage of nerehantable timber destroyed: the timber destroyed in feet B. M.: the total value of timber de-trored; the extent and character of damage to reproduction: the cost of fire to the service; and the value of conperation receired in lire fighting.

Distribution of Serrice (annual, Dec. 1).--A report for the preceding fiscal year, giving by Forests and by totals for the District the time, expressed in percentage. spent in each class of work ly oflicer's on National Forests.

Mectings (annual). - I report for the preceling fiscal rear giving the number of superrisor"s and of Ranger"s meetings, the attendance, the places at which the meetings were held, and a brief statement of their character and results.

Permument Improrements (quarterly). I cumulative report giving tabularly by clases for the District the total number of miles of rompleted projerts and the ent per unit ar per mile. The report for the quarter ending Jume 30 will con-titute the annual report, and will give tabularly by Forests and by elasses of imployments moler cach Form-t the number ur mileage of completerl projecte, the arerage cost per unit ne per mile. and the total rout: the number or mileage of uncompleted projerets. the average amomnt jer mit or per mile

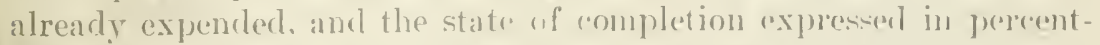
age: and, summarized by alases for the Di-trict, the total mumber

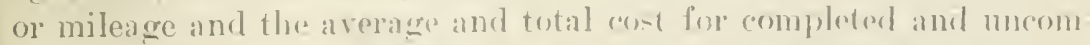
pleted projects separately. and for the latter the state of completion expre-sed in percentage.

Boundaries (monthly). - I tabulation by forests and by totals for the District, giving the area of adrlitiom and climinations made during the month, with the dates of prorlanations.

Rariger Stations (monthly). - I tabulation by Forect and by total. for the District, giving separately the number and andes of cites rommended during the month for nit lolbawal or roluse to the

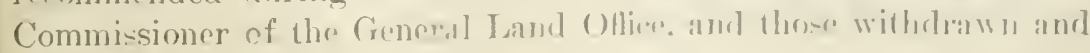
released. 
Clume (monthly). - I tabulation by Forests and by totals for the District. giving separately the number of each clase of claims mpon which report is rerplested by the commisioner of the General Land Office: of claims regarding which reconmendations have been made to the Commi-sioner with the character of the recommendation; and of cases pending, hearings ordered. patents, and cancellations. Areas will be given so far as slown by the record.

Settlement (monthly).-A tabulation by Forest and by totals for the District. giving separately the number of applieations receired. recorded. recalled hy applicant. inchded in tracts listed. rejected because the land is needed for public nse, alienated or nonagricultural. and the area linterl.

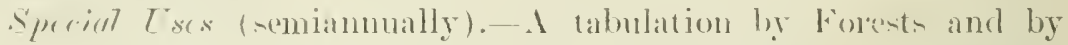
totals for the District, giving separately the number. kind, acreage, and mileage of permits issued by supervisors, issued by the Distriet Forester' and refused by the District Forester: of those recommender to the Forester for issue. issued by the Forester, recommencled to thr Forester for refusal, and refused by the Forester; of Interior I) partment (easement) applications other than railroads, recuiver by reference from ITashington, recommended for approval to the Commin-ioner of the General Land Office. approved by the feretary of the interior. recommended to the Forester for rejection, and rejected by the Secretary of the Interior: and of Interior Department Ratilroad applications received from Washington, recommended for approval, recommended for rejection. and rejected by the Secretary of the Interior.

I'evommet (quarterly).-A tabular statement of the District personnel at the end of the last quarter, giving by grades the number of employeer atrigned to each Oflice and Forest separately. and the totals by erarles for the District.

Littlefield (ammal. Oct. 20).--A report on Form 170 for the preceding fiscal year.

liereipts und liefunds (monthly).- I report on Form 27 for the preceding montl.

Liability Statrment (monthly).-A report on Forum 15s for the preceding month.

Financial Stutement (monthly). - I report on Form 2 t? for the preceding month.

Tomporary Lator (monthly). I report on the Departmental form for the preceding montl.

Timber Sold (monthly). - I tabulation by Forests and by totals for the District, giving for the preceding inonth the amomnt and valuation of timber sold and of timber cut. These reports will at the enel of each fircal year be combined into an annual report, giving the totals for the District with a supplemental report giving by For- 
ests the reduction by cancellation ol modification in the amonut of timber corered by timber-sale antrats.

Free les (ammul. Oct. 1).-I tabulation by Forests and les totals for the Distriet. giving for the preceding fixel year the number of free-use permits. and the anomut and valuation sepalrately for the green and dead timber actually chit.

Marimum f'ut (ammul, Mar. 1). - I report giving by Forests any changes mate sine the last report in the maximum ent anthorized

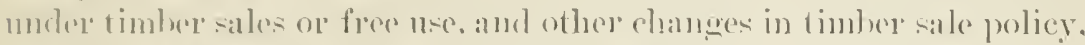
with a brief statement of the need for them.

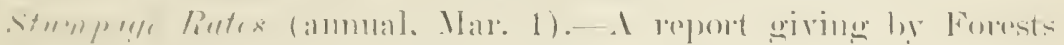

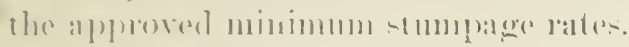

Timber sate rosts (ammuil. Sept. 1). - I report for the previous

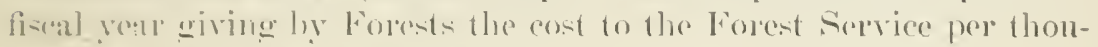
silul fien of timber sold and rent.

foupurention (ammial). I brjef summary for the preceding liseal rast of work dome in Foderal. State. and private cooperation sepalatrly and in planting and forret manacement separately under each, griving the projerts mulertalion. their ent to the service and to the

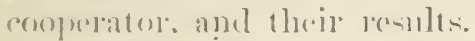

Vutiomel Fonest Planting (ammal. Mar. 1).-1 five-pear District

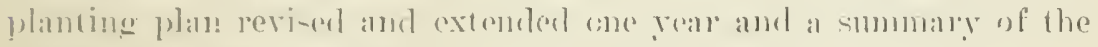
planting reports subnitferl ly Fore- Supervisons.

vileirs (anmulal. Mar. 1).-A brief smmmary of the important silvieal projerte umlertaken at Experiment stations and elsewlere, and of theid result-. and an ontline of plans for future work.

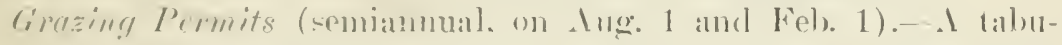

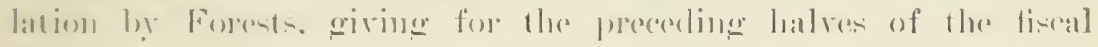
I (4)

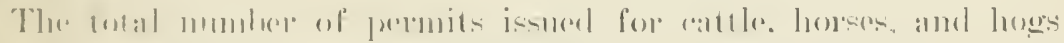

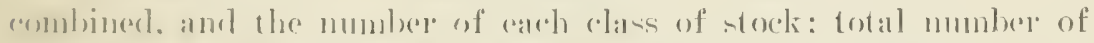
permits ismed for shecp and goats combined. and mumber of each clatse of stork: number of applicants who failer to pay glazing foes: mumber of crossing permits isured, and of each class of stock which

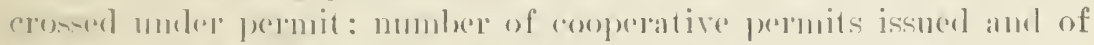

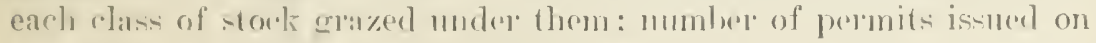

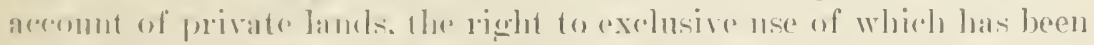

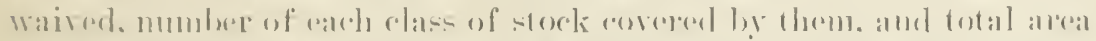

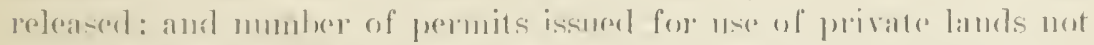

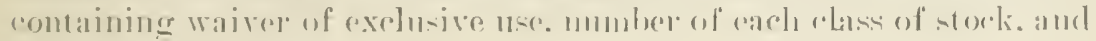
total area ionereed.

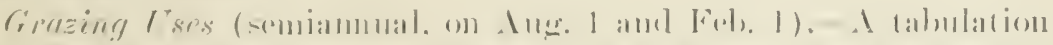
by Foress, giving the tolal mumber of all claseres of paid grazing

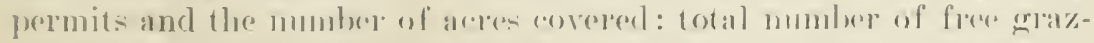

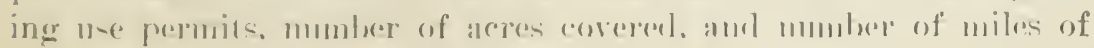


drift or division fence constructed; also, the total amount of fees received from each class of permits.

Grazing Trespass (annual. Aug. 1).-A report for the preceding fiscal rear, giving by Forests the number of grazing trespasses, illegal inclosures and grazing use trespasses, and the number separatcly of cases settled. prosecuted, closed withont settlement, and pending.

Predatory Animals (amnual, Aug. 1).--A summary for the preceding fiscal rear, of monthly reports from Supervisors (U. B., p. 149), giving by Forests the number of hunters employed and the period of employment of each, and the number separately of each kind of predatory animal killed by hunters and officers on National Forests other than hunters. A brief summary should also be given of the results obtained in the protection of fish and game on National Game Preserves.

General Range Conditions (annual, Feb. 1).-A report for the preceding calendar year, giving briefly the general condition of grazing business in the District. the results of range improrement and derelopment work completed during the year, and the work planned for the ensuing year.

Timber Tests (monthly).-Copies of monthly reports of engineers in charge of timber-testing laboratories, and of reports to cooperators in timber tests.

Timber Treatment (monthly).-Copies of monthly reports of engineer's in charge of treating plants, and of reports to cooperators in timber treatment.

General (monthly). - A brief progress report upon Marliet Stuäies and upon other investigations not conducted in timber-testing laboratories or treating plants.

\section{WASHINGTON.}

OFFICE OF THE FORESTER.

DUTIES.

The administration of the Forest Service. and the supervision of lines of work conducted in the Office of the Forester.

LAII.

DUTIES.

General supervision, throngh the District Forester, of the policy and methods of Law in District Offices; legal advice to members of the Waslington Office; approval of legal forms, documents, and correspondence: and the handling, in cooperation with other Departments and Bureats, of appellate proceedings in litigated cases; and of applications for rights of way under the wrong act. 


\section{1:บขTละ.}

\section{IDVICE:}

The routine pleseribed for Di-trict ollices will be followed, exrept that a copy of ateh formal memoramelum will be sent to each listrict Forester. Copies of formal memoranda reseived from District Oflices will be filed hy subject designation and number.

Aprovil of Legat, Forms, etc.

The routine for approval of legal documents and colrespondence. will follow that prescriber for Diatriet ()flices. All legal forms used in 11 ashington and in District Oftices, and proposed changes, must be approved by the Law Otlicer. buth for use and for inclusion in the Legal Form Book. The use of any form withdrawn by the Iaw Otlicer firm the Iegal Form Book will be discontimued.

\section{OPERATION.}

UTTIES.

The general control. thromgh the Distriet Forester. of the policy and methods of the District Oflices of Operation, and the supervision of the Offices of Ucempancy, Aceounts. Geograply, and Mantenance.

$$
\text { OCCUPANCY. }
$$

DTTIF:

Reviru and final artion mpon the recommendation of the Districts regarding hommiary projocts, and recommendations to the Department of the Interior.

Forwarling to the I)istrict Forester notices of withromal received from the (ommis-ioner of the General Lambl oflice.

Forwarting to the District Forester of applications for Forest homesteads addressed in error to Washington. and 1ransmitting to the District Forester notices from the Commissioner of the General Land Office that tracts have been declared open to entry.

Preparation for approval of Class " a" and " $d$ " permits, of stipulations in Interior Department railroad cases, and of recommendations approving the latter to the Commissone of the General I and Office.

\section{Routine.}

BOUNDARIES.

Bonndary projects submitted to the Folester will. with all correspondence involvat, be referred to the District ()lfice for recommondation.

Upon receipt of the recommendation of the I)istrict Forecter and areompanying papers. a proclamation diagram will be frepareal. maing the type and title mapo as a hasi-. Two ropies and the original of the proctamation and of the diagram will be sent to the Commis-

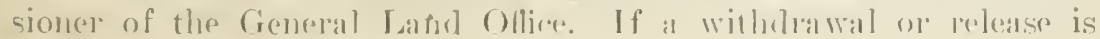


recommenterl. the recommentation and diagran only will be forwarded to the Comminioner.

Upon receipt of notice of signature of the proclamation by the President, the Distriet oflice will be notified by wire.

Upon receipt of printed proclamations from the State Department, a sufficient number will be forwarded to the Districts for distribution.

All maps, petitions, and other papers transmitted to the Forester with recommendations on boundary projects will, after final action is taken, be returned for the District files.

Boundary projects will be recorded by ard index (Form 137), which will be filed by Forests.

\section{CLAIMS.}

Requests for report and recommendations on claims received from the Commissioner of the General Land Ottice and notices of hearing and of final action will be forwarded to District offices.

SPECIAL USES.

Requests for permits and applications for rights of way in Interior Department cases will be referred to the District Forester.

The neces-ary arbons in Interior Department railroad cases will be prepared, and three blueprints will be mate, one for Washington, one for the District and one for the supervisor.

Interior Depaltment cases in which a right of way is somght muder the wrong act will be handled by the Law Officer.

Index rards for Class " a " and " $d$ " permits and Interior Department railowat rases will be filed ar precribed for the District office.

ACCOTNTS.

WeTHS.

The Washington oflice will constitute a bistrict for acconnting purposes, and in aldition will keep the accounts of the Forest Service under appropriations. will compile its fiseal statements, and will combine all I)istrict ficral statements into summarizerl reports to the Folester.

\section{RovTINE.}

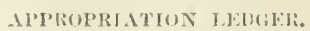

An areount with each appropriation will be kept on shede (Form 11). Whoce someres and clases of entries will he as follows:

DIEIIT.

CRIDIT.

( From Fompler"s lettrus of allotment.)

'Jhe allotments to Jistricts and changes therein, and the Fulester's rontiugrat find.

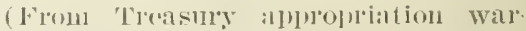
latits.) The amount of the approu'iation. 
GHNERAL ILLOTMENT LEDGER.

A - epalate account will be kept on sheets (Form 12) of each allotment (t) each Inistriet from pach appropriation, whose souress and clawern of entries will be as follows:

1):1:1T.

CRLDIT,

\section{Illuturent columu.}

( roum lorester's letters of allotment.)

"l'lu allotment to the District and challans therein. l)ecreases will be enterest in rect ink.

\section{In Mrpusits Columu.}

\section{In Disburement Columu.}

(From reytusitions for timus.) rlue allumis apploverl for aleposit to the crolit of the District Fiseal Agent aul his Sperial Disbursing Agruts. These entries will be verified by (4)mplitison with the 'lreasurer's notitiontion of wrarant issuer, and will lus completed log entry of the walllaml number.

1.rom "leasmy sottlement notices.) The anomes withdrame from the alpropliation to cover claims settleil.

I guarterly (from Accounts Current of tIre District Fiscal Igent and his Sireial Disbursing Ienuts). The disbursements.

( Fom 'Treasury Settlement nutices.) The claims settrod.

I trial balance of the General Allotment Ledger will be made quarterly after the receipt and entry of the Accounts Current, which will show for each account the net allotment, the total of approved requi-itions and Treat-nry sotlements, and the total of disbursements and claims settled by the Treasury.

The trial balance will supply lor any Inistrict or for the service as a whole the amount -till available in the Treasury and the amount to the creedit of all disbursing officers.

\section{TREASURY SFTTLEMENT OF CLAIMS.}

Sotices of Treasury settlements will be entererl in the (xeneral Allotment Ledger as a debit to funds drawn from the appropriation and as a creelit by disbursements. The notices will then be forwarded

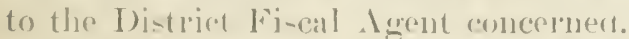

\section{RI:QUISITUNS FOK JUNUS.}

Is requisitions for funds to be placed to the creclit of IDistrict Fiecal Agrents and sperial Di-bur-ing Igents are received they will be examined to see that they do not exeres the amount available in

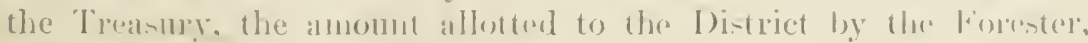
and the amonnts ar vilable molep the bonds of the dishuring allicers. 
The requisitions will then be entered in the General Allotment Ledger, and will be initialed and forwarded to the Chief of the Division of Accounts and Disbursements of the Department of Agriculture.

Notices of Warrants Issued.-The notices of warrants issued by the Treasury when received from the Chief of the Division of Accounts and Disbursements of the Department of Agriculture will be checked against the requisitions previously entered in the General Allotment Ledger. The warrant numbers will be entered and the notices sent to the District Fiscal A gent concerned.

\section{ACCOUNTS CERRENT}

The disbursements in each District under each appropriation will be entered in the General Allotment Ledger from the quarterly Accounts Current.

The Accounts Current and the accompanying abstracts and voucher will then be formarded through the Division of Accounts and Disbursements of the Department of Igriculture to the Treasury for settlement.

MONTHLY FINANCIAL STATEMIENTS.

The monthly Financial Statements from the Districts will be consolidated on Form 279.

APPOINTMENTS.

Letters to the Secretary of Agriculture recommending appointments or other action affecting salary status prepared in District offices will be signed by the Forester. If any changes are made a new letter will be written with two carbons, and one sent to the District Forester concerned.

Appointments and other orders of the Secretary of Agriculture affecting Distriet personnel will be sent to the District Forester concerned.

I.ITTLEF IELD REPORT.

Littlefield Report ( For'm 170) received from the Districts will be summarized in duplicate on the same form. The cards (Form 250 and 278$)$, after being checked against the accompanying sheets and the additions rerifierl. will each be assembled alphabetically under appropriations. Payments to the same person under the same appropriation in different Districts will be consolidated. Separate abstracts of Forms 250 and 278 will be prepared in duplicate, and with the accompanying sheets (Form 170) will be submitted to the Secretary of Agriculture. 
RECEIPTS,

Is monthly Reports of Receipts and of Refunds (Form 27) are received from Districts, the items will be entered upon Forms 28 (Forest Receipts. Forest Summary. Class Summary, and District Summary Cards). The net recoipts will then be calculated and entered. Ir comparion with the figures for the same month of the preceding fiscal year the amount and percentage of increase or decrease in gross receipts will be mtered.

AUTHORIZATIONS FOR AIVERTISING.

Letters of authorization of the secretary of Agriculture to Supervisors to advertise in certain papers will be compared with the eopy of the Forester's letters of recommendation, held in a waiting file in Iccounts. when both original and duplicate letters of authorization will be sent to the District Forester concerned.

\section{GEOGRAPIIY.}

\section{DUTIE.}

The compilation for publication of the Forest Atlas, and the execution of all drafting and status rork required in Washington, and of all laboratory work in photography required by the Forest Service. except blueprinting done in District offices.

\section{Routine:}

ATI.1S.

Data compiled in District offices, data funnished in Washington. and monthly reports on entries from the General Land Office will be posted in the Forest Atlas.

In cooperation with the United States Geological Survev. revised Itlas sheets will be compiled for publication.

\section{ALIENATION.}

Geography will upon requisition procure from the records of the General Land Oflier satus data not given in the Forest Atlas required in Washington. As monthly reports of entries are received from the General Land Office, they will be forwarded to the District office and posterl upon the Forest Atlas.

JWAFTIE.

(iengraphy will execule all clafting required in Washington. upon requicition approved by the Geographer. 
PHOTOGRAPHY.

Photography will fill requests from the Districts and from Washington for films and for developing. printing, and other photographic work. and for blueprinting required in Washington. Requests will be made on Form 9SS, and approved by the Chief of the office concerned. Photography will keep on Form 194 a current recrid of photographic work by classes.

\section{MAINTENANCE.}

DUTIES.

Naintenance will perform the same duties as those prescribed for the Section of Maintenance in District offices.

\section{ROETINE.}

The routine of the equipment and maintenance of quarters, of assistance in stenography and typewriting, and of handling mail and files will be the same as that prescribed for Maintenance in District offices.

The Chief of Maintenance in Washington, under an annual allotment from the Forester, will keep in stock stationery, office supplies. instruments. and field equipment for the use of members with headquarters in Washington, and of all other members of the Service outside the District organization. This stock will be maintained through requisition direct upon the Purchasing Agent, instead of throrigh requisition on the Property Clerk at Ogden. as prorided for Maintenance in District offices.

\section{SILVICULTURE.}

DUTIES.

The general control, through the District Foresters, of the policy and methods of Silviculture in District Offices, and the supervision of the Oflices of Federal Cooperation, State and Private Cooperation, and Silvics.

\section{ROUTINE.}

COOPERATION

The Oflices of Federal Cooperation and State and Private Cooperation will follow in their cooperative work outside the Districts the routine prescribed for similar lines of work under Timber Sales and Planting in the District organization.

\section{Silvics}

Compiled silvical data will lee filerl by species. A tile will also be maintained by National Forests. for copics of reports upon species occurring upon them, or cross references to reports on these species. 
LIBRARY.

Books for use in Washington.-Requisitions for bonks fiom the Department Iibrar will be made in ruplieate on the card form provided. and the duplicate filed in a waiting dile alphabetically by anthor, mutil the requisition is filled, and then destroverl.

subject and anthor catalogue eards will be filled out and filed alphabetically and a shelf-list card filled out and filed mumerically for each book receired.

When a book is loaned a charge eard (Form 172) will be signed by the borrower, the date entered, and the card filed alphabetically by author. A charge card (Form 185) will be filled out and filed alphabetically by name of borrower. When a book is returned the date will be entered on Form 172 over the signature of the horrower. and on Form 185. the former returned to the book pocket and the latter to the file. The file of charge cards (Form 185) will be examined on the first of each month and those who have had books over a month will be notified.

Copies of the quarterly list of new books in the Department Library, and of the monthly list of additions to the Forest Service Library, will be sent to each District Office.

Boolis for District and Supervisors Offices.-_Form ris will be prepared in duplicate as a requisition for the purchase of books for District and supervisors Oflices, the original sent to the Purehasing Clerk and the duplicate filed chronologically in a waiting file until the requisition is filled. and then destroved. Books will be receipted for on Form 939a, given the Department Library number, if any, or otherwise numbered in accordanes with the Department Library srstem.

Subject and anthor catalogue cards will be made out in duplicate. the original retained, and the duplicates sent to the District Office with llie book. Forms 172 and 185 will be filled out and the latter sent to the I)istrict Office for return and filing.

Anmally at the beginning of each calendar vear a list of books chared to each District Oflice will be sent in rluplicate to the District Foreter. who will approve one copy and returu it to Washingtom.

Perionticuls.-The receipt and filing of periodicals will be as prescribed for I)istrict ()ffices.

Catalogure careds will be filled ont and filed and priodicals loaned

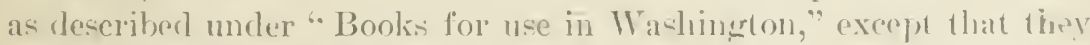
will be rassified by subjeet and title and form 172 will he filed by title.

I'lotograples. - Is receiverl. photographic motobouks will be al'-

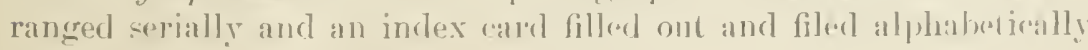
by author. 
As mounted photographs are received entries will be made on the back from the notebook in which the collection number given the photograph will be entered. The photographs will then be classified by State and subject and catalogue cards filled ont and filed by subjects.

Lantern Slides.-The Chief of Silvics will approve the loan of lantern slides, which will be classified and catalogned like photographs.

Borrowed lantern slides will be receipted for on Form 988 which will be filed alphabetically by name of borrower. As slides are returned Form 988 will be stamped "Returned."

GRIZING.

DUTIES.

The general control, through the District Forester, of the policy and methods of Grazing in the Districts, including the determination of allowances, periods, and rates, and action upon appeals from the decision of the District Forester.

ROLTINE.

Grazing Authorizations.

Upon receipt of each Superrisor's annual grazing report from the District Forester a letter of anthorization will be submitted for approval by the Secretary of Agriculture. When the letter is returned approved a letter with one carbon will be sent to the District Forester. informing him of the authorization approved by the Secretary and of the periods. rates. and special rulings established for the Forest.

Federal and State Quarantine Regulations.

At the beginning of every grazing season a statement will be obtained from the Burean of Inimal Industry and forwarded to District Foresters, of the quarantine and inspection work proposed in each district. with the names and addresses of the inspectors in charge.

\section{National fame Preserves.}

Copies of all proclamations establishing National Game Preserves will be sent to the District Forester concerned. Upon receipt from him of draft of proposed regulations it will be reviewed and submitted to the Secretary of A griculture for approval. A copy of the regulations as approved will be sent to the District Forester. 
Appeal from District Forester's Grazing Decisions.

Upon receipt of all papers in an appeal from al decision of the District Forester, the case will be reviewed, decision made, and the District Forester notified.

PRODLC'S.

DUTIES.

The general control of the policy and methods of Products in the Districts, the supervision of the Office of Publication, and the supervision of the Offices of Wood Utilization and Wood Preservation, whose routine will follow that prescribed for these lines of work in the Districts. and whose results so far as applicable will be made arailable for use in the Districts. 



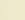






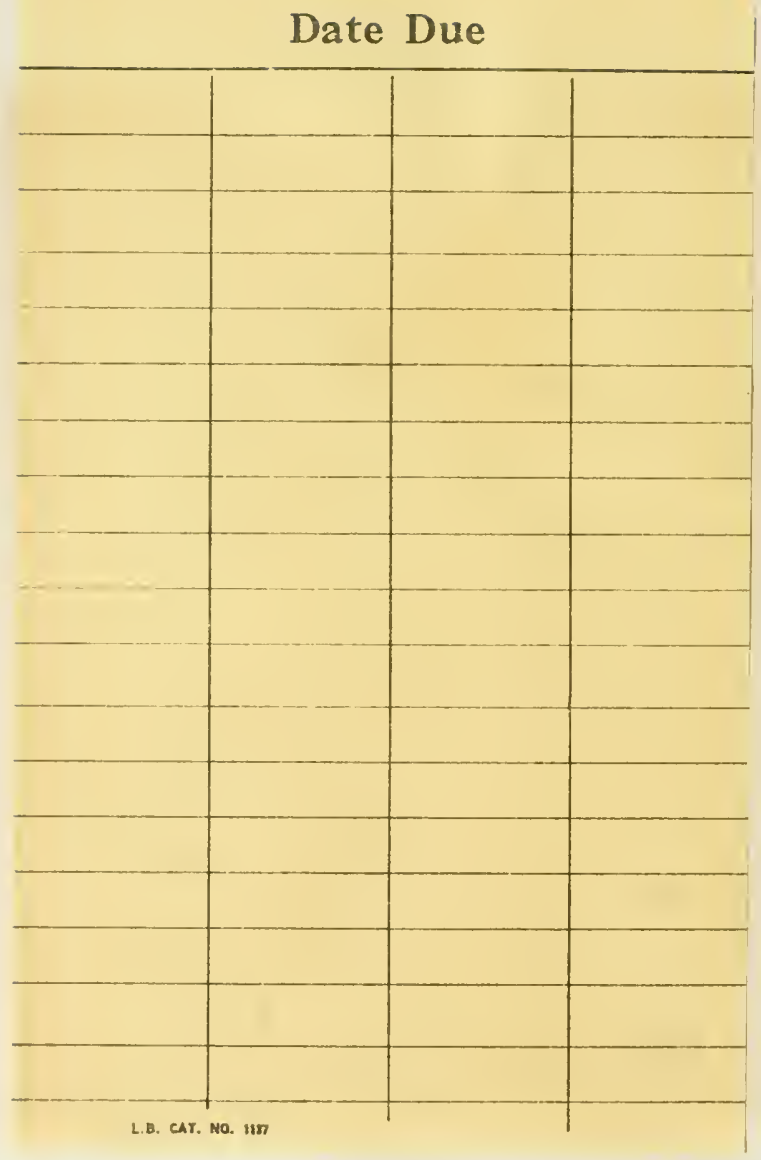


CALL NO. SD 11 II 2

AUTHOR U............ Dept. of agricultrure. Forest sorrice.

TITLE............. Nanusl .... af ...procedure.... for

LIbrary of THE UNIIVERSITY OF BRITISH COLUMBIA

\begin{tabular}{|c|c|c|c|}
\hline Date Due & Reader's No. & Date Due & Reader's No \\
\hline & & & \\
\hline & & & \\
\hline & & & \\
\hline & & & \\
\hline & & & \\
\hline
\end{tabular}


